\title{
AWAY-FROM-REACTOR STORAGE OF SPENT NUCLEAR FUEL: FACTORS AFFECTING DEMAND
}

\author{
PREPARED FOR THE U.S. DEPARTMENT OF ENERGY
}

\section{PATRICIA M. DINNEEN, KENNETH A. SOLOMON, MARK B. TRIPLETT}

\section{R-2558-DOE OCTOBER 1980}




\section{DISCLAIMER}

This report was prepared as an account of work sponsored by an agency of the United States Government. Neither the United States Government nor any agency Thereof, nor any of their employees, makes any warranty, express or implied, or assumes any legal liability or responsibility for the accuracy, completeness, or usefulness of any information, apparatus, product, or process disclosed, or represents that its use would not infringe privately owned rights. Reference herein to any specific commercial product, process, or service by trade name, trademark, manufacturer, or otherwise does not necessarily constitute or imply its endorsement, recommendation, or favoring by the United States Government or any agency thereof. The views and opinions of authors expressed herein do not necessarily state or reflect those of the United States Government or any agency thereof. 


\section{DISCLAIMER}

Portions of this document may be illegible in electronic image products. Images are produced from the best available original document. 


\section{PREFACE}

This report presents the results of an analysis of factors affecting the demand for U.S. government-provided away-from-reactor (AFR) storage of spent nuclear fuel. The purpose of the analysis is to assist policymakers in predicting more accurately the demand for government AFR storage relative to the demand for other storage options.

This work was supported by the office of Nuclear Policy and the Division of Transportation and Fuel Storage of the U.S. Department of Energy (DOE) under Contract DE-AC01-79PE-70078. Previous1y published results of Rand's research for DOE on nuclear spent fuel management include:

- K. A. Solomon, Nuclear Reactor Spent Fuel Valuation: Procedure, Applications, and Analysis, R-2239-DOE, February 1978.

- K. A. Solomon and M. B. Triplett, Valuation of Muclear Reactor Spent Fuel Using the HPG?/97 Programmable CalcuZator, N-1176-DOE, April 1979.

The present report is addressed to groups--including, especially, DOE and the Interagency Review Group on Nuclear Waste Management (IRG)--concerned with nuclear spent fuel management. 
SUMAARY

Spent nuclear fuel, resulting from nuclear power generation by domestic and foreign utilities, and the military, may either be stored temporarily (interim storage), reprocessed for further power generation, or disposed of permanently. The only option presently open, however, is interim storage, because of current U.S. policy against reprocessing and the current unavailability of repositories for ultimate disposal. Accordingly, this report focuses on the demand for interim storage. Among the options available for satisfying this demand are on-site storage by utilities, private away-from-reactor (AFR) storage facilities, and government AFRs.

This report analyzes factors that affect the magnitude and timing of demand for government AFRs, relative to the demand for other storage options, to assist policymakers in predicting this demand more accurately.

Accurate prediction has important economic and policy implications for utilities, ratepayers, and the government. Underestimation will lead to insufficient AFR storage capacity and may jeopardize the operations of utilities that do not have adequate on-site storage capabilities. They could even have to shut down their nuclear reactors temporarily, because each of the options for expanding storage capacity has lead times that range from months to years, depending on regulatory and legislative delays. Overestimation will promote the building of too much AFR capacity too early, thereby imposing an unnecessary burden on the ratepayers or taxpayers or both, who must bear a larger share of costs than they would have to if costs were spread over more users and over a longer period of time.

Unfortunately, predicting AFR demand is subject to great uncertainty, particularly with regard to future demand for nuclear energy, to costs, and to political and regulatory policies. For that reason, past predictions of AFR demand range widely and often appear to conflict. This report helps to explain the apparent conflicts among 
existing demand predictions by demonstrating their sensitivity to changes in key assumptions.

Specifically, the report analyzes factors affecting the demand for government AFR storage facilities; illustrates why demand estimates may vary; and identifies actions that may be undertaken by groups, within and outside the government, to influence the level and timing of demands.

The analysis led to the following conclusions regarding demand and recommendations for policies and actions.

\section{CONCLUSIONS REGARDING DEMAND}

The folzowing factors affect the demand for govermment AFR storage:

- Regulatory treatment of the fee for government AFR services

- The demand for nuclear energy

- Decisions regarding the future of plutonium reprocessing and breeder reactor programs in the United States

- On-site storage expansion

- Timing and availability of government AFRs

- The extent to which transshipment of spent fuel from one utility to another is permitted

- The availability of shipping casks

- The extent of foreign demand for AFRs

- How and by whom the AFR storage facilities are financed

Predicted demand for goverment AFRs may vary dramatically, depending on what assumptions are made about each of the above factors. For example, under assumptions based on maximum demand, five AFRs (with capacity for 5000 metric tons of heavy metal (MTHM)) would be required by 1993, whereas under assumptions based on minimum demand, less than one AFR of that size would be adequate.

To narrow the wide range in predicted demand requires reducing the uncertainty about the demand factors identified above. Certain 
groups may, by their policies and actions, reduce this uncertainty. In the near term (over the next five years), the groups most 1ikely to be able to do so are the utilities, the Nuclear Regulatory Commission (NRC), the Environmental Protection Agency (EPA), and the state public utility commissions (PUCs), because their actions and policies will determine how much on-site expansion takes place. In the long run (more than five years), Congress and DOE are 1ikely to be more influential than other groups in reducing uncertainty, because their actions will determine the size and availability of AFRs--Congress through enabling legislation for funding, and $\mathrm{DOE}$ through disbursement of the funds.

\section{RECOMMENDED POLICIES AND ACTIONS}

The demand for government AFRs will be highly uncertain as long as U.S. policies toward reprocessing and development of breeder reactors remain unclear. Nevertheless, specific actions such as the following may be taken now to reduce the uncertainty:

The Department of Energy (DOE) could:

- Set criteria and requirements for accepting spent fuel (e.g., cooling period, advance delivery schedules, level of on-site expansion, efforts to transship fuel, and other considerations);

- Specify the fee structure more clearly, with regard to the arrangements and timing of fee collection and with regard to whether the fee for storage will be combined with or separate from the fee for disposal;

- Sponsor research and development on shipping casks to render all casks physically interchangeable and compatible with handing equipment; and

- Establish definitive criteria in conjunction with the State Department for accepting foreign spent fuel.

The Nuclear Reguzatory Commission (NRC) could: 
- Issue regulations for on-site storage expansions and transshipments of spent fuel; and

o Issue regulations for shipping-cask design criteria.

The Environmental Protection Agency (EPA) and the Department of Transportation (DOT) could:

- Set environmental and transportation standards for on-site expansion, transfer of spent fuel, and operation of AFRs.

State public utility commissions (PUCs) and other regulatory agencies could:

- Determine the anount and speed with which utilities will be allowed to recover the costs of AFR fees, and

- Set clear rules for on-site storage expansion, transshipment, or storage of spent fuel generated in other states.

Utilities could:

- Make more definitive plans to transship spent fuel or to expand their own on-site capacities, and

- Participate in private decentralized (regional) AFRs.

Congress could:

- Authorize legislative authority and funding for an AFR. 


\section{ACKNOWLEDGMENTS}

The authors wish to thank the many people from Rand, the Department of Energy, the Congress, state public utility commissions, utilities, and the nuclear industry who contributed their ideas and constructive criticism during the various stages of our research. In particular, we wish to acknowledge the contributions of those people who carefully reviewed earlier drafts of this report, including Rand colleagues Walter Baer, Jackie Burns, Arturo Gandara, William Harris, and Leland Johnson, and Department of Energy officials David Bodde, James Fiore, Sandra Fucigna, Steven Goldberg, and Michael Lawrence.

We especially wish to acknowledge Willard Harriss for editing this report and June Fyfe and Marilyn Martino for their patience and care in typing the final version. 


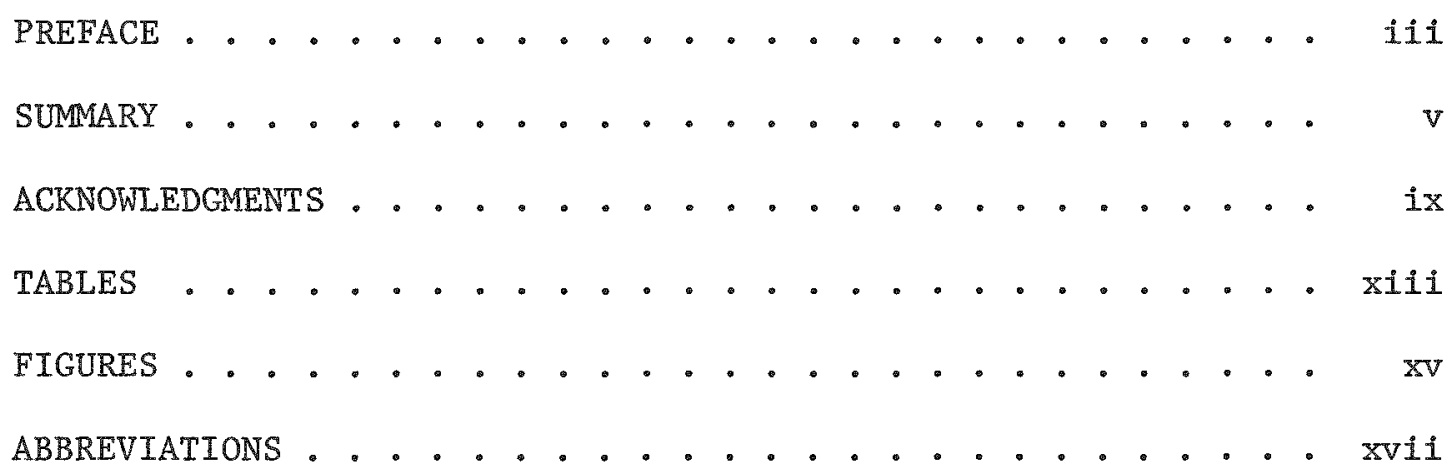

Chapter

1. INTRODUCTION . . . . . . . . . . . . . . 1

Overview . . . . . . . . . . . . . . . . 1

Policy Evolution . . . . . . . . . . . . . 1

Outline of the Study............... 5

2. ON-SITE AND AWAY-FROM-REACTOR STORAGE OPTIONS . . . . 9

On-Site Expansion Options . . . . . . . . . . . . 9

Away-From-Reactor Storage Options . . . . . . . 13

Options for U1timate Disposal of Spent Fue1 . . . . 17

3. FACTORS AFFECTING THE DEMAND FOR GOVERNMENT

AFR STORAGE .................... 19

Demand by Domestic Utilities . . . . . . . . 19

Demand by Foreign Utilities . . . . . . . . 23

Military Demand ............. 25

4. THE EFFECT ON DEMAND OF ALTERNATIVE FINANCING

ARRANGEMENTS FOR GOVERMMENT AFR's . . . . . . 28

Financing Characteristics That May Affect Demand . . 28

Major Financing Alternatives . . . . . . . . . 31

Likely Effect of Major Financing Options on Demand . . 34

5. ESTIMATING A RANGE OF DEMAND FOR GOVERNMENT AFR'S UNDER VARIOUS ASSUMPTIONS .......... 41 Categories of Assumptions Used to Define

Alternative Scenarios ........... 41

Quantifying the Scenarios ........... 43

6. EXPLAINING THE DIFFERENCES IN DEMAND PROJECTIONS . . . 50

Critical Parameters and Assumptions ........ 50

Groups with Power to Affect the Values of Critical

Parameters ............... 52

The Extent to Which Each Group Can Influence AFR

Demand . . . . . . . . . . . 56 
Actions and Policies That Support or Oppose

Each Scenario . . . . . . . . . . 56

7. FINDINGS AND RECOMMENDATIONS . . . . . . . . . 59 


\section{TABLES}

1.1. Schedule of Nuclear Generating Capacity and Spent Fuel Discharges, Annual and Cumulated .......... 3

1.2. Varying Estimates of Fuel Storage Capability . . . . . . 6

2.1. Extent and Cost of Recent Storage Capacity Expansions . • 11

2.2. Estimated Cost of On-Site Storage Expansions Relative to a 5000-MTHM AFR ............. 13

2.3. Estimated Cost and Schedule for Upgrading Existing Facilities . . . . . . . . . . . . 15

3.1. Estimates of Foreign Spent Fuel Delivered to the United States: Three Scenarios . . . . . . . 26

4.1. Characteristics of Major Financing Options That May Affect Demand . . . . . . . . . . . . 35

4.2. Likely Impact of Alternative Financing Options on Demand ................... . 37

5.1. Nuclear Waste Storage and Disposal Scenarios and Assumptions ................ 44

6.1. Extent to Which Each Critical Parameter Affects the Demand for Government AFRs . . . . . . . . . . 52

6.2. Assumptions for Critical Parameters of the Three Scenarios ............... . 53

6.3. Extent of Influence Various Groups Have on Critical Parameters . . . . . . . . . . . . . 54

6.4. Extent to Which Government, Public, and Private Groups Can Affect AFr Demand . . . . . . . . . . . 56

6.5. Actions That Support or Oppose DOE's Implementation of Three Scenarios . . . . . . . . . . . . 60 
1.1. (a) Spent Fuel Storage Options with Immediate Reprocessing . . . . . . . . . . . 8

1.1.(b) Spent Fuel Storage Options with Delayed or No Reprocessing . . . . . . . . . . . . 8

2.1. Capita1 Costs of "Away From Reactor" Storage Facilities . . . . . . . . . . . . 12

5.1. AFR Demand Estimates for Domestic Participation . . . 46

5.2. AFR Demand Estimates for Domestic and Foreign Participation ........................ 47

7.1. AFR Requirements for Each Scenario......... 60 

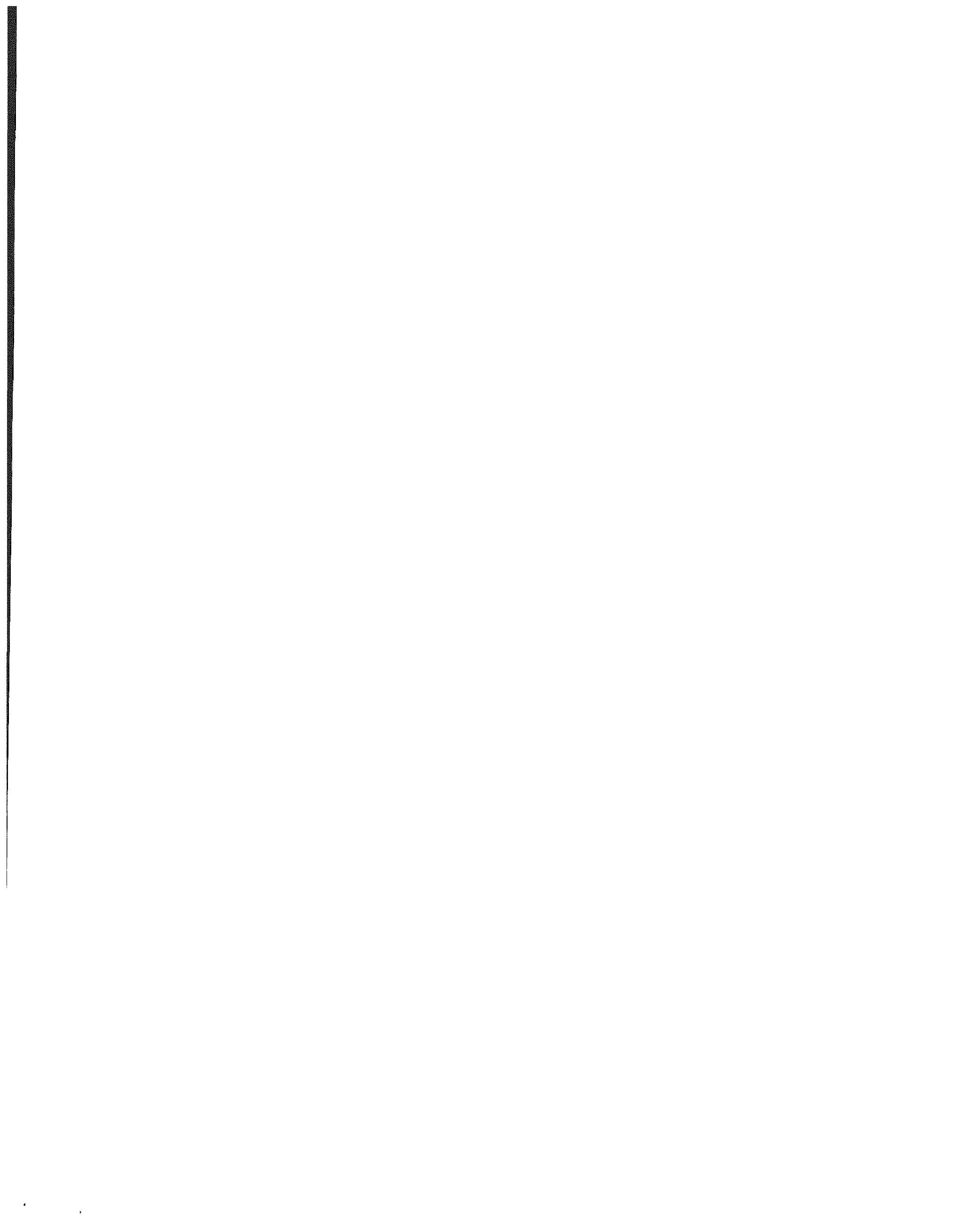

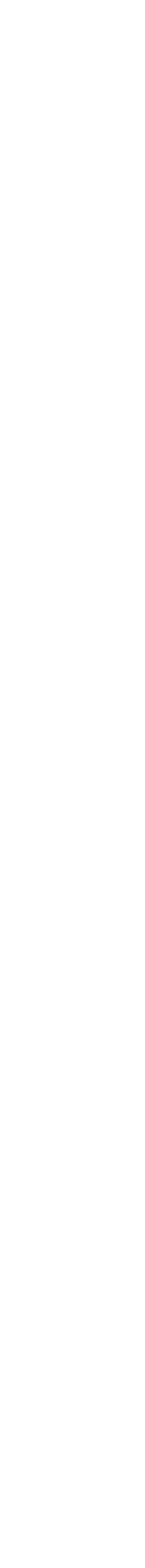




\section{ABBREVIATIONS}

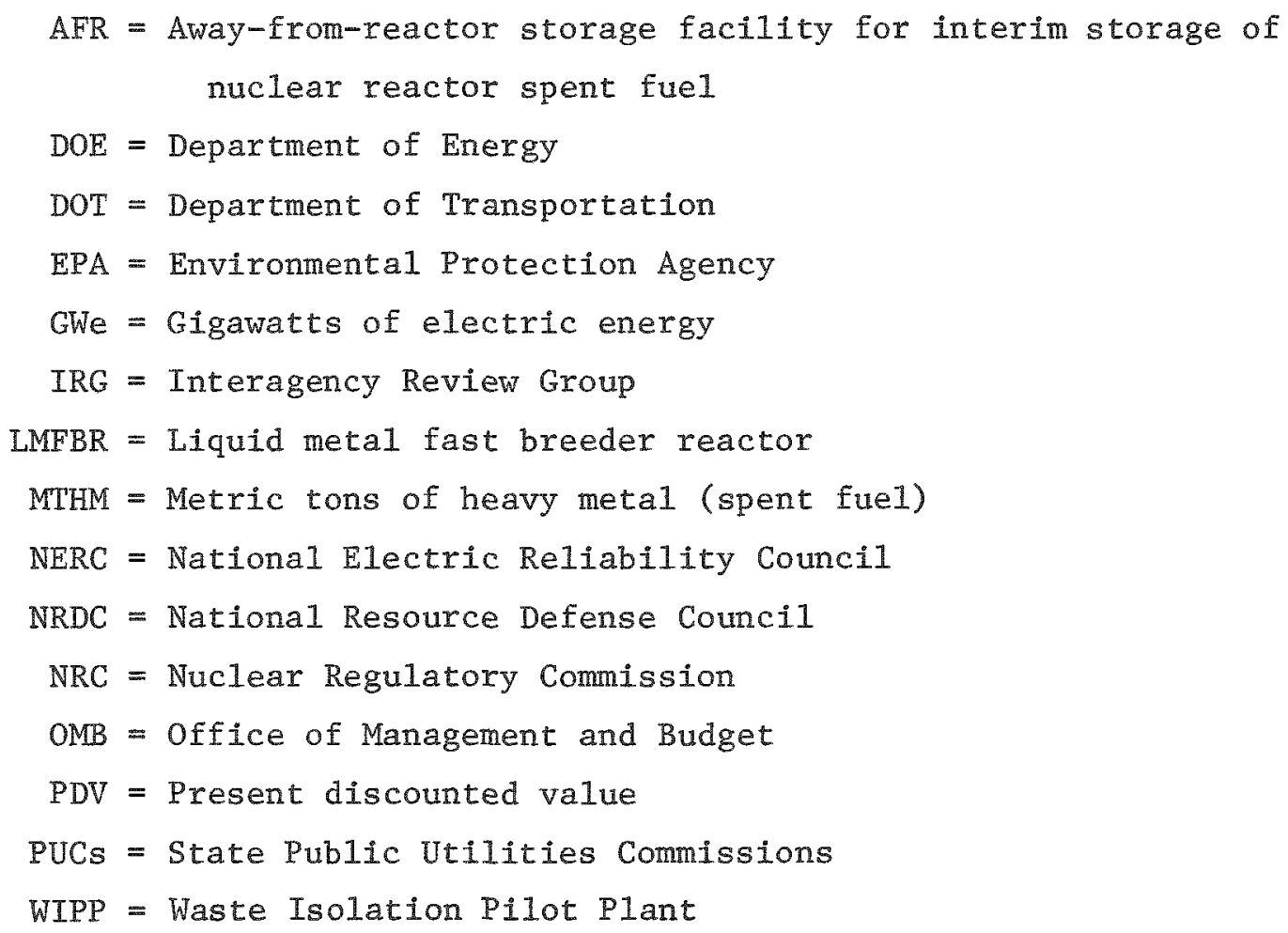


Chapter 1

INTRODUCTION

\section{OVERVIEW}

This report develops a conceptual framework for analyzing the demand for government away-from-reactor (AFR) spent fuel storage facilities. The report then applies this framework to generate a representative range of possible demand levels, in order to demonstrate the sensitivity of demand predictions to changes in assumptions about several key factors. Because great uncertainty surrounds such key factors as the future costs of interim storage, demand for nuclear energy, and regulatory and political policies, it is extremely difficult to predict future demand. Consequently, wide variation is to be found in reported estimates of when and how much government AFR storage capacity will be demanded by domestic and foreign sources.

In this report, we attempt to narrow the range of demand predictions. Our approach is to identify and analyze factors affecting demand; explain why, and illustrate by how much, various demand estimates differ; and identify actions that groups within and outside the government can take to influence the level and timing of demand, so as to enable more accurate predictions of AFR demand.

\section{POLICY EVOLUTION}

To understand the Department of Energy's current nuclear spentfuel policy, it is important to examine how and why the concept of a government AFR storage program evolved.

Until three to four years ago, most utilities operating nuclear power plants (hereafter called nuclear utilities) intended to reprocess their spent nuclear fuel and recycle unused plutonium and uranium. On Apri1 7, 1977, however, President Carter announced that the United States would defer all commercial reprocessing of spent nuclear fuel indefinitely and would encourage other countries to do 
the same. This action eliminated (or at least postponed) the option for marketing the fuel and meant that utilities had to store more spent fuel than they had originally planned when providing for their own on-site storage capacity.

This reprocessing deferral has resulted in an increasing requirement for spent fuel storage capacity. For example, spent fuel at existing and planned reactors in the United States has been projected to continue accumulating at the rate indicated in Table 1.1. On October 18, 1977, prompted by limited and decreasing on-site storage capacity at reactors, the Department of Energy (DOE) announced a new spent fuel policy which under certain conditions would permit DOE to take title to and store spent fuel for a one-time storage and/or disposal fee. This offer was extended to both domestic utilities and foreign governments.

Methodologies to aid in determining the federal charge to utilities for spent fuel storage were developed independently by The Rand Corporation, ${ }^{1}$ TRW Energy Systems, ${ }^{2}$ and Pacific Northwest Laboratories. ${ }^{3}$ A preliminary estimate of the federal fee was released by DOE in July 1978. 4 The fee for combined AFR storage and disposal services ranged from $\$ 250$ to $\$ 300$ per kilogram (kg) of spent fuel, and the fee for AFR storage only, ranged from $\$ 150$ to $\$ 250$ per $\mathrm{kg}$. Reaction to the DOE estimated fee and fee.methodology, as reported by the Interagency Review Group (IRG) was generally favorable. ${ }^{5}$ The major debate

\footnotetext{
$1_{\mathrm{K}}$. A. Solomon, Nuclear Reactor Spent Fuel Valuation: Procedure, Application, and Analysis, The Rand Corporation, R-2239-DOE, February 1978.

${ }^{2}$ Economics of National Waste Terminal Storage: Spent Fuel Pricing Study, TRW Report Y/OWI/SUB-78/42512/2, May 1978.

3 M. K. White et al., Sensitivity of the Federal Fee for Managing Spent Fuel to Financial and Logistical Vamations, Battelle-PNL Report PNL-2637/UC-70, June 1978.

${ }^{4}$ Preliminary Estimates of the Charge for Spent Fuel Storage and Disposal Services, Department of Energy Report DOE/ET-0055, July 1978.

5 Report to the President by the Interageney Review Group on Nuclear Waste Management, U.S. Government Report TID-28817, July 1978.
} 
Table 1.1

SCHEDULE OF NUCLEAR GENERATING CAPACITY AND SPENT FUEL DISCHARGES, ANNUAL AND CUMULATED

\begin{tabular}{l|c|c|c}
\hline & \multirow{2}{|c}{$\begin{array}{c}\text { GWe Capacity } \\
\text { of Reactors } \\
\text { Discharging }\end{array}$} & \multicolumn{2}{|c}{ Spent Fuel Discharged (MTHM) } \\
\cline { 2 - 3 } Year & $\begin{array}{c}\text { Spent Fue1 } \\
\text { Spent }\end{array}$ & Annual & Cumulated \\
\hline 1976 & 38 & 820 & 2,500 \\
1977 & 43 & 940 & 3,400 \\
1978 & 53 & 1110 & 4,500 \\
1979 & 60 & 1260 & 5,800 \\
1980 & 68 & 1410 & 7,200 \\
1981 & 74 & 1660 & 8,900 \\
1982 & 96 & 1950 & 11,000 \\
1983 & 101 & 2110 & 13,000 \\
1984 & 105 & 2260 & 15,000 \\
1985 & 105 & 2340 & 18,000 \\
1986 & 105 & 2340 & 20,000 \\
1987 & 105 & 2250 & 22,000 \\
1988 & 150 & 3210 & 25,000 \\
1989 & 167 & 3560 & 29,000 \\
1990 & 186 & 3960 & 33,000 \\
1991 & 205 & 4360 & 37,000 \\
1992 & 223 & 4740 & 42,000 \\
1993 & 244 & 5210 & 47,000 \\
1994 & 265 & 5660 & 53,000 \\
1995 & 285 & 6090 & 59,000 \\
1996 & 307 & 6520 & 65,000 \\
1997 & 328 & 6940 & 72,000 \\
1998 & 347 & 7310 & 80,000 \\
1999 & 366 & 7630 & 87,000 \\
2000 & 383 & 7920 & 95,000 \\
\hline & & & \\
\hline & & &
\end{tabular}

SOURCE: U.S. Nuclear Regulatory Commission, Genewic Environmental Impact Statement on Hondling and Storage of Spent Iight Water Power Reactor Fuel, NUREG-0404, March 1978.

NOTE: Data through 1985 are from individualized reactor characteristics at 0.6 plant factor; for years 1986-2000, data are based on 0.7 plant factor.

$a_{\text {MTHM }}=$ metric tons heavy metal. An additional 360 MTHM was stored at the Nuclear Fuel Services plant in West Valley, New York, and at the General Electric plant in Morris, Illinois. 
concerned when the fee should be made final with no subsequent adjustments.

Following the July 1978 Report, several other policy-relevant events occurred. In November 1978, the Spent Fuel Project office was established at the Savannah River (DOE) Field Office. In December 1978, draft Generic Environmental Impact Statements on both domestic ${ }^{6}$ and foreign fuels ${ }^{7}$ were issued.

In January 1979, DOE proposed legislation before Congress to implement its announced spent fuel policy. The legislation stipulates that the government will take title to domestic and foreign spent fuel upon receipt of a one-time fee for storage and disposal, and that a revolving fund will be established to finance the AFR program. After holding hearings on the proposed legislation, however, the House Commerce Subcommittee on Energy and Power in early April 1979 rejected DOE's request to establish a revolving fund for spent fuel management. Instead, the Committee amended the authorization bill to allow $\$ 30$ million for the program and requested further studies on the need for a government AFR Program.

The lack of clearly defined criteria for acceptance of spent fuel, uncertainty about the estimated level and timing of demand for government AFR facilities, and the desirability of financing the program with a revolving fund of the proposed magnitude have caused Congressional concern over the proposed legislation. Critics of the DOE-proposed AFR Program complain that the DOE has not considered these points adequately and that several DOE-sponsored studies concerning the estimated level and timing of demand have some conflicting conclusions.

For example, during 1978 and the first part of 1979, several different estimates of AFR storage requirements were published. Two

${ }^{6}$ Charge for Spent Fuel Storage: Draft Environmental Impact Statement, Department of Energy Report DOE/EIS-0041-D, December 1978.

${ }^{7}$ Draft Environmental Impact Statement on the Storage of Foreign Spent Power Reactor Fuel, Department of Energy Report DOE/EIS-0040-D, December 1978. 
studies that clearly conflict are the DOE-sponsored Stoller study 8 and the National Resource Defense Council (NRDC) study. ${ }^{9}$ Because their assumptions about the extent to which the private sector will provide for its own storage needs differ, they have different views about when the reactors will lose full core reserve space on-site, as shown in Table 1.2. In estimating the loss of full core reserve at individual reactors, the two studies differed by 10 years or more at 5 reactor sites and 7 years or more at 14 reactor sites.

In response to continuing Congressional, utility, and private sector concerns over whether there is a need for a government AFR, and if so, when and of what size, this report develops a conceptual framework for analyzing these concerns. It does so by demonstrating how differences in assumptions about costs, political and regulatory policies, and the behavior of certain interest groups may lead to a wide range of estimates of the demand for government AFRs (see Table 1.2). Having identified certain factors that affect demand, the report then recommends actions that certain groups, including the federal government, Congress, utilities, the private sector, and public interest groups, might take to influence the level and timing of demand.

OUTLINE OF THE STUDY

To develop a conceptual framework for analysis, we begin by examining, in Chap. 2, the range of options available for storing spent nuclear fuel generated by domestic utilities, foreign utilities, and the military.

Due to the present U.S. government policy opposing plutonium reprocessing, and the current unavailability of repositories for ultimate disposal, all spent nuclear fuel must be temporarily stored either on-site or at private, U.S. government, or foreign AFR

${ }^{8}$ Spent Fuet Storage Requirements-The Need for Away-FromReactor Storage, Department of Energy Report DOE/ET-0075, February 1979.

${ }^{9}$ Results of the NRDC survey have been reported in Nuclear Fuel, April 2, 1979, pp. 2-4. 
Table 1.2

VARYING ESTIMATES OF FUEL STORAGE CAPABILITY

\begin{tabular}{|c|c|c|}
\hline \multirow[b]{2}{*}{ Utility } & \multicolumn{2}{|c|}{$\begin{array}{l}\text { Estimated Loss of Full } \\
\text { Core Reserve Space Based on: }\end{array}$} \\
\hline & $\begin{array}{l}\text { DOE/Stoller } \\
\text { Assumptions }\end{array}$ & $\begin{array}{l}\text { NRDC } \\
\text { Assumptions }\end{array}$ \\
\hline San Onofre & $(1978)^{a}$ & 1991 \\
\hline Humboldt Bayb & $(1979)^{a}$ & 1986 \\
\hline Brunswick -1 & $(1980)^{a}$ & $1987(1992)^{c}$ \\
\hline Brunswick -2 & 1981 & $1988(1992)^{\mathrm{C}}$ \\
\hline Nine Mile Point- -1 & 1981 & 1991 \\
\hline Diablo Canyonm-1 & 1982 & 1988 \\
\hline Robinson- -2 & 1982 & 1992 \\
\hline Diablo Canyon--2 & 1982 & 1989 \\
\hline Yankee-Rowe & 1982 & 1995 \\
\hline Hatch -1 and 2 & 1983 & 1995 \\
\hline Prairie Island -1 and 2 & 1983 & 1992 \\
\hline Zimmer--1 & 1984 & 1992 \\
\hline Oyster Creek & 1984 & $1987(2000)^{c}$ \\
\hline Fort Calhoun & 1984 & After 1985 \\
\hline Rancho Seco & 1985 & 1992 \\
\hline Arkansas -1 and 2 & 1985 & 1986 \\
\hline Maine Yankee & 1985 & 1992 \\
\hline Susquehanna--1 $b$ & 1985 & 1994 \\
\hline Trojan & 1985 & 1985 \\
\hline
\end{tabular}

NOTES: DOE offers "four basic reasons for the differences" between the DOE data and the NRDC data. The NRDC disputes them and offers "one important difference." [No Need For AFR, by the National Resource Defense Council, March 1, 1979, Dimitri Rotow.] The four DoE reasons are: (I) In some cases (e.g., Oyster Creek), utility plans have changed since December 31, 1973, DOE estimate; (2) in some cases (e.g., Robinson, San Onofre), reactors lose full core reserve for one or two years but then regain it when another storage basin at a new reactor becomes available; (3) DOE has differing assumptions from those of NRDC; (4) DOE contends that NRDC has internal inconsistencies.

In disputing each of those reasons for why DOE and NRDC estimates differ by so much, the NRDC cites only one reason why they differ: ". . the most important difference is that $D O E^{\prime} s$ findings are based on 'current planning." If expansion of pools is possible and reasonable, but the utility simply has made no commitment to do so, this capacity would not show up in DOE's analysis. NRDC, on the other hand, asked the utilities what they realistically thought they could accomplish, including what they would do if the Government AFR were not available.

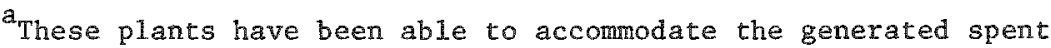
fuel.

Reactor is nonoperational.

${ }^{\mathrm{c}}$ Stoller allows for transshipments, by several plants, from one reactor to another. If this assumption is added to the NRDC survey data, the estimated date of loss of full core reserve is extended to the year in parenthesis. 
facilities. Figure 1.1(a) shows storage options when cooled spent fuel is reprocessed immediately and recycled. Little on-site storage is needed. However, as Fig. 1.1(b) shows, with delayed or no reprocessing, additional storage options such as expanded on-site storage, a government $A F R$, or a private AFR are needed. Of course, a permanent disposal facility would alleviate the shortage of on-site space by direct disposal of spent fuel; but currently no such facility exists. If reprocessing resumes after one or more AFRs are operational, the demand for additional AFRs would be reduced.

Chapter 3 focuses on some factors affecting the level and timing of demand for government AFRs, such as the relative cost of expansion at the reactor site compared to the fees for government AFRs, and the varying technical and regulatory requirements that limit onsite storage expansion. Chapter 4 is a detailed examination of how financing options may affect demand for government AFRs. Next, we specify different sets of assumptions for each of the demand parameters in Chap. 5. Our scenarios span a representative range of minimum and maximum demands for government AFRs. We also define a "base" case derived from DOE/ET-0075, Spent Fuel Storage Requirements-The Need for Away-From-Reactor Storage (February 1979).

To illustrate the extent to which differences in assumptions about critical parameters can lead to wide ranges in demand estimates, we generate demand estimates for each scenario and evaluate differences.

Finally, in chap. 6, we identify and evaluate policy tools and actions that various governmental and nongovernmental groups may undertake to effect the realization of each demand scenario defined in Chap. 5. Chapter 7 presents our conclusions and recommendations. 


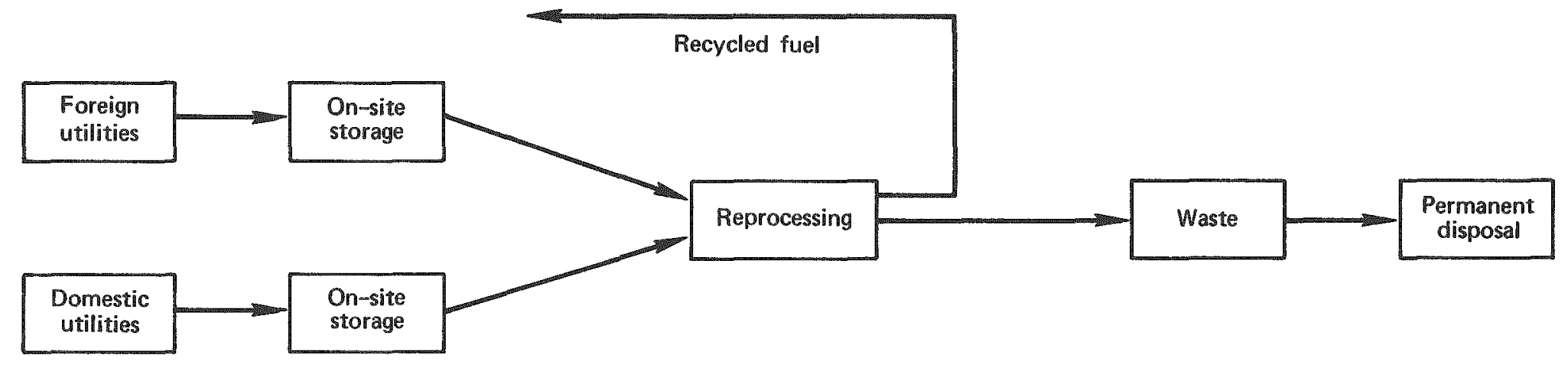

Fig. 1.1 (a) - Spent fuel storage options with immediate reprocessing

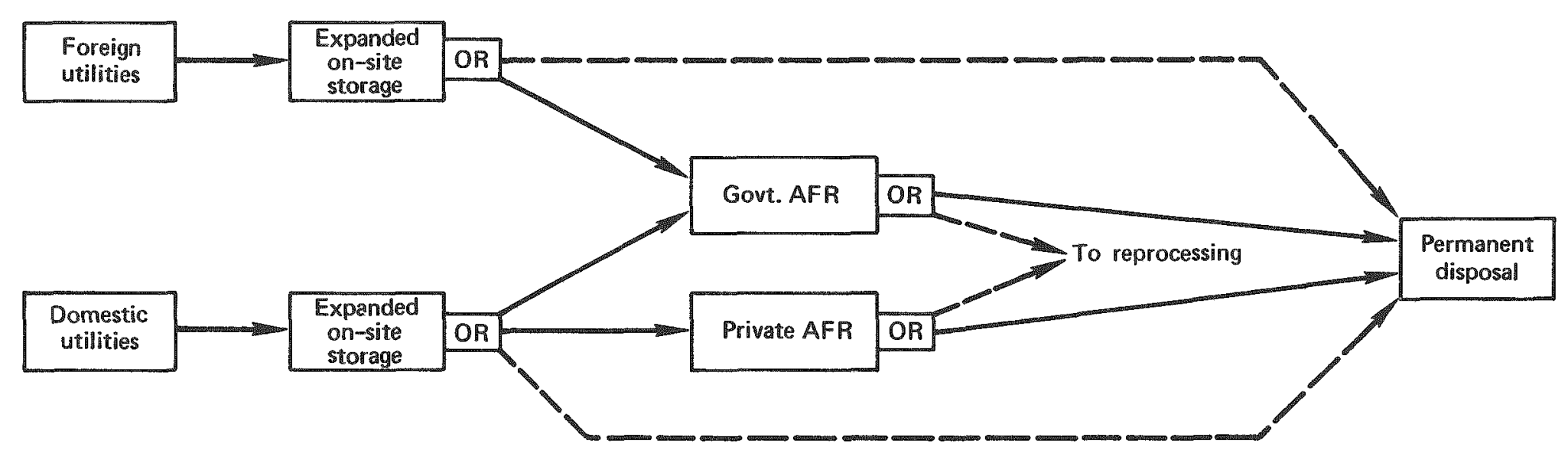

Fig. 1.1(b) - Spent fuel storage options with delayed or no reprocessing 
Chapter 2

ON-SITE AND AWAY-FROM-REACTOR STORAGE OPTIONS

This chapter enumerates the major storage options both at reactor sites (i.e., on-site) and at AFR centralized facilities, and indicates how they differ in their relative costs, technical characteristics, regulatory requirements, lead times required for regulatory approval and construction, and relative potential for satisfying the expanding demand for storage capacity.

To calculate the comparative unit costs $(\$ / \mathrm{kg})$ of the different options, we calculate the present discounted value (PDV) of all capital and operating costs for a particular option and divide by the present discounted value (PDV) of the quantity of stored fuel, measured in kilograms ( $\mathrm{kg}$ ), over the full expected useful lifetime. Expressed in mathematical form:

$$
\text { Unit cost }(\$ / \mathrm{kg})=\frac{\mathrm{PDV} \text { (costs) }}{\text { PDV (kg spent fuel in storage) }} \text {. }
$$

\section{ON-SITE EXPANSION OPTIONS}

On-site spent fuel storage expansion options include using existing storage space more effectively by either reracking or using higher concentrations of neutron absorbers in the water, or both; and expanding on-site pool volume.

\section{More Effective Use of Existing Storage Space}

Methods for achieving more effective use of existing storage space include:

- Reracking

-- Filling unused pool areas with existing types of racks or racks of different design.

- Replacing nonfuel racks with racks that can accept fuel.

-- Replacing old racks with racks of closer spacing. 
- Using a higher concentration of neutron absorbers (e.g., boron in the pool water).

- Combination of the above.

Storage pool reracking and compaction methods permit increases in storage capacity of from 1.5 to 4 times the original capacity. Recent expansions and current plans suggest an average on-site expansion of 2.5 times the original capacity. The actual figure, however, will depend on certain technical limitations due to criticality considerations (influenced by spacing between assemblies and the concentration of neutron absorbing boron) and total pool heat load. For example, neutron absorption techniques permit use of racks of closer spacing, but the pool temperature must be maintained below $40^{\circ} \mathrm{C} .1$

Regulatory requirements also may determine the extent and rate of storage capacity expansion. For example, the period of design through installation is typically 18 months, $^{2}$ and the NRC must approve each application. ${ }^{3}$ Few, if any, regulatory constraints have arisen, but legislation pending in Massachusetts would prohibit increases of on-site storage capabilities beyond "the original design specifications. $" 4^{4}$

Cost for modifications to existing facilities typically range from $\$ 1$ million to $\$ 2$ million (in current dollars). Reported unit costs range from $\$ 5 / \mathrm{kg}$ to $\$ 40 / \mathrm{kg}$, depending upon the extent of

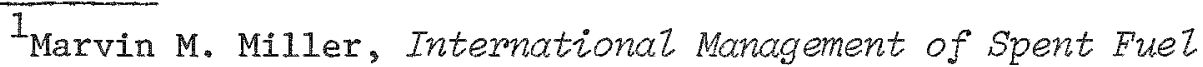
Storage: Technical Altematives and Constraints, MIT Energy Laboratory, Report No. MIT-EL 78-012, June 1978.

${ }^{2}$ U.S. Nuclear Regulatory Commission, Genemic Environmental Impact Statement on Handling and Storage of Spent Light Water Power Reactor Fuel, NUREG-0404, March 1978.

3 Most currently operating reactors have either completed such changes or have applied to NRC for future expansions.

4 In January 1979, bi11 number MA-H2346 was introduced. This bi11 "would prohibit the expansion of spent fuel storage capacity at commercial nuclear reactors beyond original design specifications," NRC State Progrom Report, February 2, 1979. 
modifications to the existing pool. Table 2.1 shows typical costs.

Expansions of On-Site Pool Volume

A second way to increase on-site storage capabilities is to expand pool volume by enlarging the existing pool or by adding an additional pool at the site.

Increasing pool volume is subject to several constraints. For example, cooling requirements pose a technical constraint. For large expansions, the cooling system would require upgrading, which would add significantly to the cost. Furthermore, to enlarge the existing pool, the pool liner must be penetrated. With spent fuel already in place, the NRC would prohibit this activity, and thus this option applies only to new reactors or those under construction. Finally, in view of the costs, technical requirements, additional land and new construction required, state regulations are more likely to constrain this option than the compaction or reracking options.

Table 2.1

EXTENT AND COST OF RECENT STORAGE CAPACITY EXPANSIONS

\begin{tabular}{|c|c|c|c|c|c|c|c|}
\hline \multirow[b]{2}{*}{ Reactor } & \multirow[b]{2}{*}{ Type } & \multirow{2}{*}{$\begin{array}{l}\text { Size } \\
\text { (MWe) }\end{array}$} & \multicolumn{2}{|c|}{$\begin{array}{c}\text { Storage Space } \\
\text { Assemblies }\end{array}$} & \multirow{2}{*}{$\begin{array}{l}\text { Increase } \\
\text { in } \text { MTHM }^{\mathrm{T}}\end{array}$} & \multirow{2}{*}{$\begin{array}{l}\text { Total } \\
\text { Capital } \\
\text { Cost (\$) }\end{array}$} & \multirow{2}{*}{$\begin{array}{c}\text { Unit } \\
\text { Cost } \\
(\$ / \mathrm{kg})\end{array}$} \\
\hline & & & Before & After & & & \\
\hline Typical & PWR & $2(1100)$ & 340 & 868 & 238 & $1,243,000$ & 5.4 \\
\hline Typica1 & BWR & 548 & 740 & 1650 & 173 & $1,989,000$ & 17.1 \\
\hline Point Beach & PWR & $2(497)$ & 208 & 351 & 64 & $2,200,000$ & 35.5 \\
\hline Maine Yankee & PWR & 790 & 318 & 953 & 286 & $1,620,000$ & 9.0 \\
\hline Fort Calhoun & PWR & 457 & 178 & 614 & 83 & 898,700 & 4.1 \\
\hline
\end{tabular}

SOURCE: NRC, Generic Environmental Impact Statement on Fanding and Storage of Spent Light Water Power Reactor Fuel, NUREG-0404, March 1978.

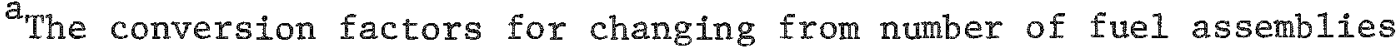
to MTHM are:

$$
\begin{aligned}
\text { MTHM = } & \text { (no. of fuel assemblies) } \times 0.19 \text { for boiling water } \\
& \text { reactors (BWRs); } \\
\text { MTHM = } & \text { (no. of fuel assemblies) } \times 0.45 \text { for pressurized } \\
& \text { water reactors (PWRs). }
\end{aligned}
$$


With regard to costs, the DuPont Savannah River Laboratory (SRL) has compared capital cost estimates for water basin storage and obtained the composite estimate ${ }^{5}$ shown in Fig. 2.1. Using the SRL scaling data for water basin storage, we use Eq. (2.1) to calculate unit costs for on-site expansions, and can then compare these costs with those of a 5000 MTHM AFR, using the same cost model (Table 2.2). As is evident from these data, economies of scale exist for water basin storage because, as the facility size increases, more efficient use is made of the cooling system, naterial handing and transfer equipment (crane, etc.), and operating personnel.

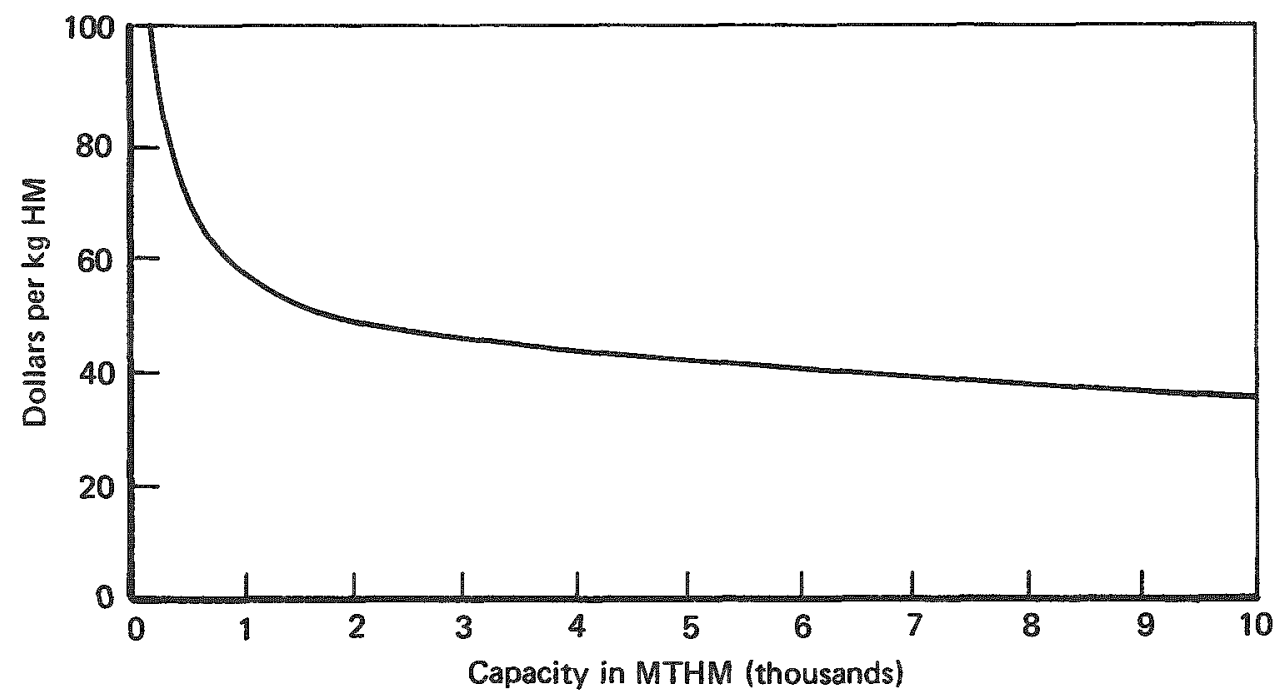

Note: Figure shows capital cost per unit of capacity; thus, a 5000-MTHM AFR would have a unit capital cost of roughly $\$ 45 / \mathrm{Kg} \mathrm{HM}$ and a total capital cost of $\$ 225$ million.

Fig. 2.1 - Capital costs of "Away From Reactor" storage facilities (Savannah River Laboratory, Storage Cost for Spent Power Reactor Fuel, DPST-AFR-79-100, January 1979) 
Table 2.2

ESTIMATED COST OF ON-SITE STORAGE EXPANSIONS

RELATIVE TO A 5000-MTHM AFR

\begin{tabular}{|c|c|c|c|}
\hline $\begin{array}{l}\text { Additional } \\
\text { Storage } \\
\text { Capacity } \\
\text { (MTHM) }\end{array}$ & $\begin{array}{l}\text { Capital } \\
\quad \text { Cost } \\
\text { (\$ million) }\end{array}$ & $\begin{array}{l}\text { Unit Cost } \\
(\$ / \mathrm{kg} \mathrm{FM})^{\mathrm{a}}\end{array}$ & $\begin{array}{l}\text { Additional } \\
\text { Annual Discharges } \\
\text { Permitted from a } \\
\text { 1000-MWe Reactor }\end{array}$ \\
\hline $\begin{array}{c}200 \\
400 \\
1000 \\
5000(\mathrm{AFR})\end{array}$ & $\begin{array}{r}18 \\
29 \\
60 \\
225\end{array}$ & $\begin{array}{l}\sim 190 \\
\sim 165 \\
\sim 130 \\
\sim 60^{c}\end{array}$ & $\begin{array}{r}7 \\
14 \\
14^{b} \\
--\end{array}$ \\
\hline
\end{tabular}

SOURCE: Data for the 5000-MTHM AFR are from Savannah River Laboratory, Storage Cost for Spent Power Reactor Fuel, DPST-AFR-79-100, January 1979.

${ }^{a}$ Capital costs are derived from Fig. 2.1; operating costs are assumed to be $\$ 2 \mathrm{million} /$ year for facilities under 1000 MTHM and $\$ 5$ million/year for the 5000-MTHM AFR. All unit costs were calculated with Eq. (2.1), with a discount rate of 8 percent. These unit costs are self-consistent in that one model generated the results, but the magnitude of these estimates may differ from those made by other sources because of different financing assumptions.

b Annual' discharges into the 1000-MTHM facility are assumed to arrive from two 1000-MWe reactors, rather than from a single reactor.

$C_{\text {We }}$ assume that AFR construction takes three years, with capital costs incurred of 15 percent the first year, 35 percent the second, 40 percent the third, and 10 percent on decommissioning. We also assume that spent fuel arrives uniformly through the first five years of operation.

\section{AWAY-FROM-REACTOR STORAGE OPTIONS}

AFR storage options include use of existing and new government and private facilities. Options under consideration include: storage at existing reprocessing facilities, including the Barnwel1, West Valley, and Morris plants; a new government facility; a privately owned and operated AFR; and a system of small AFRs servicing utility regions. 


\section{Storage at Existing Reprocessing Facilities}

Several reprocessing facilities with spent fuel storage basins could be enlarged to provide AFR storage. Spent fuel is currently stored at the Nuclear Fuel Services (NFS) plant in West Valley, New York, and at GE's Morris, Illinois plant. Allied-General Nuclear Service's (AGNS) reprocessing plant in Barnwe1I, South Carolina, could also store spent fuel after some modification.

Both the West Valley and Morris plants could receive spent fuel under emergency circumstances, but any substantial contribution to the nation's storage capabilities would require expansion and upgrading of the existing facilities. Legal actions could prohibit use of the Morris plant as a federal AFR, ${ }^{6}$ however, and DOE is currently negotiating with the State of New York concerning the disposition of radioactive wastes stored at West Valley. One suggested approach is for DOE to take charge of the waste in return for use of West Valley as an AFR. Opposition from environmental groups is expected, however. Expansion of the Barnwell plant is not favored by South Carolina's governor at this time. This attitude reflects the sentiment that each state should handle its own nuclear waste. 7

Table 2.3 shows the estimated cost, potential contribution, and schedules for upgrading existing facilities.

Although storage at existing reprocessing facilities may be the only way to meet AFR demand in the next five years (assuming al1 on-site expansions have been completed), DOE cannot implement this option instantaneously. Site selection must first await completion of the NEPA (National Environmental Policy Act) process. Next, a final generic environmental impact statement (EIS) must be

\footnotetext{
${ }^{6}$ In April 1979, Illinois Attorney General William Scott filed suit to prohibit the use of GE's Morris plant as a federal AFR (Nucleonics Week, April 19, 1979, p. 9). In addition, the Illinois Senate introduced a bill banning the storage of out-of-state spent fue1. (Nucleonies Week, May 17, 1979, p. 9).

7 Mucleonics Week, "A Major Waste Management Bill," December 13, 1977 , pp. 8-9.
} 
Table 2.3

ESTIMATED COST AND SCHEDULE FOR UPGRADING EXISTING FACILITIES

\begin{tabular}{|c|c|c|c|c|c|c|c|c|}
\hline \multirow[b]{2}{*}{ Facility } & \multirow{2}{*}{$\begin{array}{c}\text { Existing } \\
\text { Capacity } \\
\text { MTHM }\end{array}$} & \multirow{2}{*}{$\begin{array}{c}\text { Current } \\
\text { Use } \\
\text { MTHM }\end{array}$} & \multicolumn{3}{|c|}{ 1st Expansion } & \multicolumn{3}{|c|}{ 2d Expansion } \\
\hline & & & Capacity & $\begin{array}{l}\text { Schedule } \\
\text { Months }\end{array}$ & $\begin{array}{l}\text { Cost } \\
(\$ M)\end{array}$ & Capacity & $\begin{array}{l}\text { Schedule } \\
\text { Months }\end{array}$ & $\begin{array}{l}\text { Cost } \\
(\$ M)\end{array}$ \\
\hline Barnwe11 & 400 & 0 & 1100 & 30 & 16 & 5000 & 51 & 110 \\
\hline GE Morris & 750 & 300 & 1800 & 36 & $N A^{a}$ & 4800 & 60 & 125 \\
\hline NFS/West Valley & 260 & 200 & 900 & 18 & NA & NA & NA & NA \\
\hline
\end{tabular}

SOURCE: Energy Daily, "The Dilemma Over Spent Fue1," February 1, 1979, pp. 4-6. NA = Not avaîlable.

completed and must be followed by a site-specific EIS. Consequently, the construction schedules in Table 2.3 depend upon completion of the requisite hearings and EISs.

\section{Storage at a New Government Facility}

As an alternative to using existing facilities, another option is to build a new government facility.

To realize economies of scale (recall Fig. 2.1), storage capacity of a new facility would range from 5000 MTHM to 10,000 MTHM. The AFR would have an annual receiving rate of 2000 to 3000 MTHM. DOE estimates the capital cost of a 5000-MTHM AFR at $\$ 290$ mil1ion. 8 Assuming operating costs of $\$ 5$ million per year leads to an average unit cost of $\$ 77 / \mathrm{kg}$ of heavy metal. (See Table 2.2 for additional assumptions upon which this estimate is based.)

The process of site selection and approval could be a formidable barrier to this option. With an AFR in place, there are reasons in favor of locating a repository--that is, a facility for ultimate disposal--at the same site. For example, co-location of an AFR and a repository would save much of the current cost of

\footnotetext{
Energy Daily, "The Dilemma Over Spent Fuel," February 1, 1979, pp. 4-6. This capital cost estimate is higher than that reported by the Savannah River Laboratory, and consequently leads to a higher unit cost, $\$ 70 / \mathrm{kg}$ HM versus $\$ 60 / \mathrm{kg} \mathrm{HM}$.
} 
transporting spent fuel from reactor to $A F R$ and $A F R$ to repository. Furthermore, co-location may help to counter the arguments of some intervenor groups who wish to permit transportation of spent fuel only from the reactor to a licensed repository, because they view transportation to an AFR as an unnecessary risk. Such fears could inhibit state concurrence in AFR siting. Moreover, the view that each state or region should provide its own nuclear waste storage and disposal has grown in popularity and would further inhibit the siting of one centralized AFR.

\section{Storage at a Privately Owned AFR}

Another option, as an alternative to a new government facility, is to provide storage at a privately owned AFR. For example, TVA has proposed a 4500-MTHM water basin storage facility at an estinated capital cost of $\$ 300$ million. ${ }^{9}$ Using our prior assumptions, this capital cost estimate leads to a unit cost of $\$ 88 / \mathrm{kg} \mathrm{HM}$. 10

Theoretically, the capital costs of a privately owned facility should not differ substantially from those of a government facility, as described in the previous section. However, differences in the cost of capital and other financial parameters would lead to a slightly higher actual storage charge for private AFRs.

\section{Storage at Sma11 Distributed AFRs}

Alternatively, instead of a single, large, privately owned AFR, there could be a system of small AFRs, with storage capacities in the range of 1000 to 2000 MTHM, servicing geographic or National Electric Reliability Council (NERC) regions. ${ }^{11}$ Existing or planned multiunit nuclear sites could supply locations for distributed AFRs. However,

\footnotetext{
${ }^{9}$ Ibid.

10 For the purpose of comparison, this estimate was derived in a fashion identical to that used for the government AFR (see footnotes to Table 2.1).

${ }^{11}$ Savannah River Laboratory.
} 
most of the requirements faced by on-site expansions and 1arge AFRs would apply to distributed AFRs.

With regard to relative costs, in a study of the distributed AFR storage concept for DOE's Savannah River Operations office, SRL showed distributed AFRs to be more expensive than large national AFRs by a factor of at least 1.5 , depending on assumptions of foreign participation.

OPTIONS FOR ULTIMATE DISPOSAL OF SPENT FUEL

The accumulation of spent fuel generates a demand not only for interim storage, but also for ultimate disposal. Even though approximately 95 percent of the radioactivity of spent fuel decays after about 10 years of storage, the remaining radioactivity must be contained for nearly 1000 years before decaying to a level not threatening to humans. At this time, however, there is still uncertainty about the relative costs, technical characteristics, regulatory requirements, and potential capacities of repositories for the ultimate disposal of nuclear spent fuel. There is even uncertainty about the ultimate form of the disposed materials $(e . g$, whether spent fuel rods, waste encased in glass or the like) and the ultimate geologic medium (such as salt mines, seabed, and so on).

Current repository designs call for capacities of from 30,000 MTHM to 50,000 MTHM, depending upon certain technical factors. ${ }^{12}$ Given potential logistics problems with an initial repository that may limit its receiving rate, ${ }^{13}$ the need for AFR storage may continue even after the first repository becomes operational. For the first repository, 14 DOE is considering two alternative approaches. Under

12 The selected geologic medium will have a maximum heat load that will limit the density of stored material and thus the overall capacity of a given site. Initial repositories will operate so as to maintain retrievability of the waste for some number of years. This period will in turn influence the permissible heat load.

${ }^{13}$ T. B. Cochran and A. R. Tamplin, Nuclear Waste: Too Much Too Soon, Natural Resources Defense Council, May 1, 1978.

${ }^{14}$ U.S. Department of Energy, "The Nuclear Waste Management Strategy for the Department of Energy--Draft," May 21, 1979. 
the first, DOE would review existing site investigations and select one in 1982. Construction could be completed by 1988, with initial operation between 1988 and 1992. Under the second alternative, DOE would decide on the first repository site only after investigating a broader range of geologic environments, e.g., seabed disposal, in which case initial operation would not begin before 1992 and possibly not until 1995. Delays beyond this schedule do not seem unlikely and would further reduce the potential contribution of a repository in the timeframe of this study.

Siting of a repository is likely to be a long and arduous process. Recent experience with the Waste Isolation Pilot Plant (WIPP) in New Mexico has aroused skepticism concerning both the technical and political feasibility of nuclear waste disposal.

In view of the great uncertainty about options for ultimate disposal of spent fuel, this report focuses primarily on the options for interim storage, recognizing, however, that the demand for interim storage may be increased and intensified by delays in the availability of repositories for disposal.

With the major storage options identified, Chap. 3 examines certain factors that favor government AFRs over other storage options. 
Chapter 3

FACTORS AFFECTING THE DEMAND FOR GOVERNMENT AFR STORAGE

This chapter explores the decisionmaking process of potential domestic, foreign, and military customers in choosing between government AFR storage facilities and the other storage options enumerated in Chap. 2. Our analysis of the factors affecting demand is based on an investigation of numerous private and government studies, journal and newspaper articles, Congressional testimony, and interviews with representatives of the nuclear industry, the utilities, the government, the Congress, and state public utility commissions. These sources offer a wide range of opinion regarding specific factors and their relative importance. For the purpose of analysis, however, we summarize this information by classifying the most consistently identified factors into several general categories. Furthermore, we consider separately the demand by domestic, foreign, and military sectors, in view of fundamental differences in their political constraints and choices.

DEMAND BY DOMESTIC UTILITIES

Before discussing factors that are likely to affect AFR demand by domestic utilities, we need to explain that not all utilities can be expected to exhibit identical demand behavior.

For example, a utility's demand for government AFR storage and disposal services may be expected to differ depending on whether the utility is publicly or privately owned and operated. Ownership matters because public and private utilities are subject to different kinds of taxation (e.g., a private utility must pay federal, state and local taxes, whereas a public utility pays no federal taxes), which may affect how much revenue must be raised for full cost recovery of AFR fees.

Another condition that may distinguish the behavior of particular groups of utilities is whether or not their state regulatory commissions are aggressive and cost-conscious. Some state regulators may 
regard the relative costs of on-site expansion versus AFR fees as more important than other factors in considering regulatory approval. Accordingly, there may be a higher expectation of full and timely cost recovery if the state regulatory commission is cost-conscious and aggressive, and there may be greater opportunities for expediting regulatory reviews and licensing procedures.

Also, utilities that already depend heavily on nuclear power may exhibit different demand behavior from that of utilities that depend only minimally or not at all on nuclear power. Utilities contemplating new or additional investments in nuclear reactors may be subject to more stringent regulations to provide full, on-site, lifetime storage capacity. Utilities that already depend heavily on nuclear power may have a more urgent demand for off-site storage, especially if they have already taken steps to maximize on-site expansion, such as compaction.

Because of these differences among utilities in ownership, stringency of state regulation, and degree of dependency on nuclear energy, we may expect differences in the level and timing of their demand for government AFR facilities. In particular, we may expect then to assign greater or lesser importance to various demand factors. These demand factors may be grouped into the seven major categories described below.

Factors Affecting Domestic Demand

The Magnitude, Structure, and Regulatory Treatment of the Fee. Demand may vary with the magnitude of the fee depending on how much the utility is willing to pay for a given amount of storage capacity at a certain time. If the fee is high relative to the costs of the alternative storage options in Chap. 2, such as on-site expansion or small private distributed AFRs, demand for government AFRs will be reduced. For example, DoE estimates of the fee range from $\$ 250$ to $\$ 300$ per kilogram $(\mathrm{kg})$ for AFR storage and disposal, and from $\$ 150$ to $\$ 250$ per $\mathrm{kg}$ for AFR storage only. These fees are based on average (fu11) costs, including a proportion of historical sunk costs, research and development, and current fixed costs. The fee estimates 
also include average transportation costs from utility to AFR. Further, the fee may be proportionately higher for some utilities if it is differentiated according to the quality (intensity) of the spent fuel or the timing and urgency of the utility's demand (e.g., whether or not government AFR storage constitutes the utility's last resort or whether other storage options are available). Such price discrimination will discourage demand by utilities facing the higher fees.

Demand will also be affected by the structure of the fee and its regulatory treatment. For example, if the fee is a one-time fixed charge, not subject to change for at least a minimum specified period, it would reduce uncertainty regarding price. The utility's state regulatory commission might then be more likely to grant faster and more complete cost recovery through rate increases (e.g., by allowing rapid amortization and the establishment of tax-exempt advance reserve accounts for future full cost recovery). In turn, that will increase a utility's willingness to pay the fee.

In contrast, a fee that includes a risk (or contingency) premium in case of unanticipated cost increases, accidents, or failures of storage and disposal facilities, and which therefore requires utilities to share the liability for risk, will discourage demand.

Another consideration that will affect both the level and timing of demand is whether the fee combines both storage and disposal or applies to disposal only. Separating the storage decision from the disposal decision allows a utility greater flexibility in choosing among near-term interim storage options, for which costs and constraints are more certain than they are for ultimate disposal. It also allows the utility more flexibility in choosing how long to store spent fuel on-site before paying the fee for ultimate disposal, in contrast with the case of a combined fee that requires a utility to pay for disposal at the same time it pays for interim storage.

Total Expected Demand for Nuclear Energy. The quantity and timing of a utility's demand for storage and disposal facilities derive from its expectations about the level and rate of future demand for nuclear energy. Its plans for generating nuclear power to meet a share of the 
total demand will determine the rate at which it expects to accumulate spent fuel.

Political Decisions Regarding Reprocessing and the Breeder

Program. Demand will vary depending on whether or not a utility expects the government to reverse its decision about reprocessing (i.e., resuming operations), within the near future (e.g., the next 10 years), and to accelexate the breeder reactor program. In particular, demand will be dampened if the utility believes it can "se11" spent nuclear fuel, in the future, at a price that will at least cover interim on-site storage costs; or "buy back" provisions from government AFRs are such that, in the future, it would cost the utilities more to buy back their spent fuel than they could recover by reprocessing.

On-site Expansion. Demand for government AFR storage will be influenced by whether a utility expects to be able to provide sufficient on-site storage capacity (over the lifetime of the reactor) and to satisfy certain future regulatory standards (regarding health and safety, environmental protection, and nonproliferation) with its existing or planned on-site storage capabilities. To the extent that the utility expects to face shortages of on-site capacity and to encounter costly regulatory delays or regulatory and legislative restrictions against major on-site expansions (such as the construction of new pools), then its demand for government AFR storage may increase accordingly.

Timing of Availability of Government AFR Storage Facilities and Repositories. Uncertainty regarding possible delays in the availability of government AFR storage facilities and repositories will reduce utility demand if utilities expect to run out of on-site storage capacity before government facilities are available (in which case they might be motivated to undertake a large-scale, on-site expansion program of their own or invest in a private AFR facility).

Furthermore, demand will be influenced by the acceptance criteria that DOE specifies for deliveries of spent fuel, which may restrict the access or timing of access by certain utilities. For example, if DOE specifies a long cooling time prior to delivery 
(e.g., 5 to 10 years or more), during which time the utility expects to run out of on-site storage capacity, it may decide to go ahead and invest in its own major on-site expansion effort, large enough to provide for current and future needs (especially if by doing so it can capture economies of scale), thereby reducing future demand for government AFR storage. Other acceptance criteria may affect demand by assigning highest or exclusive delivery priorities to those utilities that are expected to run out of on-site storage capacity first (i.e., "last resort" cases). In this case, demand by utilities considered of lower priority will be reduced.

Extent to which Transshipment of Spent Fuel Is Allowed. Demand for government AFR storage will slacken if transshipment of spent fuel is permitted from one reactor to another within utilities and from one utility to another. In either case, approval is required by NRC, EPA, and DOT, and may also be required by state public utility commissions (PUCS) and other state agencies, including state legislatures, if transshipments involve the transfer of spent fuel from one state to another.

Availability of Shipping Casks. The extent to which shipping casks are not available in sufficient quantities at the desired time, and are not physically interchangeable or compatible with handling equipment, may reduce the demand for government AFR storage and increase utilities' incentives for undertaking major on-site expansions.

DEMAND BY FOREIGN UTILITIES

We would expect foreign utilities' demand for U.S.-supported AFRs to be affected by at least three factors. ${ }^{1}$

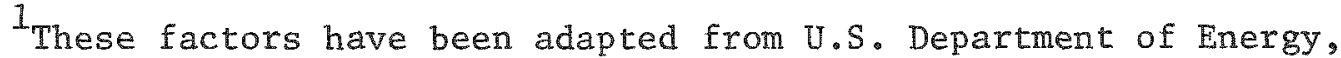
Spent Fuel Storage Requirements: The Need for AFR Storage, DOE/ET0075, February 1979. For additional detail on storage of foreign spent fuel, see: U.S. Department of Energy, "Draft Environmental Impact Statement, Storage of Foreign Spent Power Reactor Fuel," Report DOE/EIS-0040-D, December 1978.
} 


\section{Returns from Countries in Sensitive Regions}

Acceptance of spent fuel from countries in areas where international tensions are high may be decided on a case-by-case basis. In some countries there may be a potential for violent conflict, or the nuclear program itself is a source of tension. Spent fuel may also come from countries that have agreements with the United States for peaceful use of nuclear power, and from selected countries without such agreements. Because conditions in these countries can change rapidly over time, they cannot be reliably forecast.

\section{Inadequate Foreign Storage Capabilities}

On-site reactor storage basins are filling up at foreign reactors. To provide a nonproliferation benefit, transfer would be offered to countries that have no immediate alternative. The intent would be to avoid commercial reprocessing, whether as a direct or indirect consequence of continued policies. Generally, transfers from sma11, nonnuclear weapon states would be included.

This category of countries resembles the preceding one, but also includes:

- Cases in which reprocessing is likely to be a probable alternative to storing fuel in the United States.

- Cases in which U.S. acceptance would be offered under terms that would encourage the sending country to develop alternatives to national reprocessing, including investigation of multinational or national storage facilities.

- A larger number of cases in which adherence to the Nonproliferation Treaty or similar actions might be encouraged.

\section{Fuel Assurance Contracts}

The United States must approve transfers of spent fuel of U.S. origin purchased under fuel assurance contracts. The contractors 
thereby provide an additional mechanism for recovering spent fuel from foreign countries. For estimates of demand under this category, we assume that transfers are included in the prior categories.

The estimates of foreign spent fuel deliveries in Table 3.1 were obtained through detailed studies of individual countries. However, eventual participation may differ from these estimates for many reasons that will be explained below.

One reason is a foreign country's decision to participate in any spent fuel storage program depends in part on its cost relative to alternative actions, e.g., reprocessing. Thus, if a country has the opportunity to sell its spent fuel for reprocessing (either domestically or in a third country), then it may choose not to transfer its spent fuel to the United States-for a fee.

If it were in the interest of the United States (e.g., for nonproliferation or political reasons) to encourage transfers from certain foreign countries, the United States might be willing to negotiate a fee for spent fuel to compare favorably with the value of foreign reprocessing and thereby increase foreign demand.

Another reason for uncertainty about the eventual level of foreign demand is that perhaps one-half of all foreign spent fuel potentially available for U.S. storage was generated in heavy water reactors (HWRs). Because criticality ${ }^{2}$ is not a concern in storing HWR spent fuel, it requires only one-fourth of the capacity required to store an equivalent amount of other spent fuel.

Finally, international arrangements for spent fuel storage are currently under consideration; if they are concluded, most if not all spent fuel otherwise destined for U.S. storage would be diverted.

\section{MILITARY DEMAND}

Military nuclear wastes have been generated since World War II as a by-product of fissile material production for U.S. weapon programs.

${ }^{2}$ Criticality can be described as an unsafe situation resulting from too dense a compaction of fissionable material, leading to an uncontrollable neutron generation which, if unchecked, could lead to material meltdown with a large release of radionuclides. 
Table 3.1

ESTIMATES OF FOREIGN SPENT FUEL DELIVERED TO THE UNITED STATES: THREE SCENARIOS

(In tota1 MTHM)

\begin{tabular}{|c|c|c|c|c|c|c|}
\hline \multirow[b]{3}{*}{ FY } & \multirow{2}{*}{\multicolumn{2}{|c|}{$\begin{array}{c}\text { Countries } \\
\text { in Sensitive } \\
\text { Regions (Option 1) }\end{array}$}} & \multicolumn{4}{|c|}{ Nonprolifexation Benefits } \\
\hline & & & \multicolumn{2}{|c|}{$\begin{array}{l}\text { Low Option } \\
\text { (Option 2) }\end{array}$} & \multicolumn{2}{|c|}{$\begin{array}{l}\text { High Option } \\
\text { (Option 3) }\end{array}$} \\
\hline & Annual & Cumulative & Annua1 & Cumulative & Annual & Cumulative \\
\hline 1983 & 110 & 110 & 220 & 220 & 541 & 540 \\
\hline 1984 & 50 & 160 & 125 & 340 & 417 & 960 \\
\hline 1985 & 65 & 225 & 95 & 435 & 443 & 1400 \\
\hline 1986 & 70 & 295 & 140 & 575 & 620 & 2020 \\
\hline 1987 & 80 & 375 & 115 & 690 & 540 & 2560 \\
\hline 1988 & 90 & 465 & 195 & 885 & 440 & 3000 \\
\hline 1989 & 95 & 560 & 210 & 1095 & 480 & 3480 \\
\hline 1990 & 110 & 670 & 220 & 1320 & 530 & 4010 \\
\hline 1991 & 115 & 785 & 230 & 1550 & 600 & 4610 \\
\hline 1992 & 120 & 905 & 240 & 1795 & 660 & 5270 \\
\hline 1993 & 130 & 1035 & 250 & 2045 & 750 & 6020 \\
\hline 1994 & 135 & 1170 & 265 & 2310 & 830 & 6850 \\
\hline 1995 & 145 & 1315 & 285 & 2595 & 900 & 7750 \\
\hline 1996 & 150 & 1465 & 305 & 2900 & 970 & 8720 \\
\hline 1997 & 160 & 1625 & 330 & 3230 & 1080 & 9800 \\
\hline 1998 & 170 & 1795 & 350 & 3580 & 1170 & 10970 \\
\hline 1999 & 180 & 1970 & 375 & 3955 & 1260 & 12230 \\
\hline 2000 & 190 & 2160 & 400 & 4355 & 1350 & 13580 \\
\hline
\end{tabular}

SOURCE: U.S. Department of Energy, Spent Fuel Storage Requirements: The Need for AFR Storage, DOE/ET-0075, February 1979.

The waste is in the form of high-level and low-level liquid wastes stored at the Hanford Reservation, the Savannah River Laboratory, and the Idaho National Engineering Laboratory. Spent fuel rods exist but are likely to be reprocessed. Military demand for DOE AFR storage space is therefore expected to be minimal, but demand for disposal services is another matter. Clearly, all military waste must be permanently disposed. Disposal requirements for military waste differ from those for commercial spent fuel because of differences in form, content, and activity level. 
AFR costs could be reduced by siting a DOE AFR at an existing military reservation, to the extent that administration, security, monitoring, and transportation services could be shared. 
Chapter 4

THE EFFECT ON DEMAND OF ALTERNATIVE FINANCING

ARRANGEMENTS FOR GOVERNMENT AFR'S

In this chapter, we first discuss the financing characteristics that may affect the demand for government AFR storage facilities. Next, we identify five major financing alternatives and briefly describe their demand characteristics. Finally, we suggest how each of these financing alternatives is likely to affect the demand for government AFRs.

FINANCING CHARACTERISTICS THAT MAY AFFECT DEMAND

The method of financing AFR storage and disposal facilities may affect the demand for them, depending on who pays whom, how much, when, and for what. For example, demand depends on whether facilities are publicly or privately controlled, whether financing is based on U.S. Treasury rates or private capital market rates, whether fees are collected early, at the time of power generation, or later, at the time of delivery, and whether fees include both storage and disposal or disposal only.

Below, we group the financing characteristics into seven categories and explain how each may influence demand.

Decisionmaking Control

Demand for AFR storage and disposal services may depend on whether the government, the utilities, or private firms exercise primary control over decisions about the size and scheduling of facilities, fees, and acceptance criteria. To the extent that a utility perceives that it has limited or no power over such decisions, it may accordingly reduce its demand.

Distribution of the Cost Burden

Each method of financing allocates cost burdens among different 
groups, over time. For example, cost burdens are allocated between the govermment (taxpayers) and the utilities (ratepayers), and between current and future generations of taxpayers and ratepayers. Furthermore, in the short run the cost burden may be allocated disproportionately among utilities, according to the feasibility and relative costs of their opportunities for on-site expansion. The extent to which a given financing method allocates costs directly to those who benefit, instead of requiring one group to subsidize another, may influence demand, particularly if the group that is bearing the cost burden perceives that it is subsidizing another group.

Separate or Combined Fees

Whether or not the financing (and fee) for disposal is linked to the financing (and fee) for storage may influence demand by utilities, particularly those utilities whose on-site storage expansion opportunities are cheaper than the (combined) fee for AFR storage and disposal. In other words, a combined fee may not adequately reflect the preferences of a utility that has strong demand for disposal services, but 1ow demand for AFR storage services.

\section{Time of Collection}

Because the timing of collection affects the cash-flow of the group that is financing the services, as well as the group that is buying them, it may be expected to influence demand. For example, if fees are collected early (e.g., at the time of power generation), the group buying the services faces a possible negative cash flow, which may reduce its demand. If fees are collected later (e.g., at the time of spent fuel delivery), the financing group is 1ikely to experience a negative cash flow and the group buying services, allowed to defer payments, may therefore have increased demand.

\section{Cost Recovery by Utilities}

The speed with which utilities are allowed to recover AFR storage and disposal costs (fee payments) from customers, and the extent 
to which they are allowed to incorporate their share of the financing costs of different options in their regulated rate base, are likely to influence the attractiveness of different financing options and, accordingly, their relative demand for AFR services. For example, if one option allows utilities to incorporate financing expenses in their rate base, but another allows them to account such expenses only as "operating costs," then they may favor the former--which allows them to earn a rate of return on their share of the capital investment. 1 Furthermore, if a financing option allows utilities to pass through their share of the costs more completely and rapidly and with greater certainty than alternative options, then utilities will have a greater demand to participate directly in such an option.

Financing Source

Financing costs will be affected by whether capital is borrowed from the U.S. Treasury at low-interest government rates or from private capital markets at high-interest rates. To the extent that the higher costs of financing from private capital markets are reflected in higher fees, under different financing alternatives, demand will accordingly be reduced.

Degree of Flexibility and Reversibility

In view of the great uncertainty about future costs, demand, national security considerations, and political and regulatory policies, financing options that allow some flexibility of choice among utilities, over time, may influence demand. For example, options that offer separate fees for storage and disposal and for disposal only allow the utility greater flexibility in the event of changes in the relative costs of on-site storage expansion, reprocessing

$1_{\text {Electric }}$ utilities are subject to rate-of-return regulation, according to which they are allowed to expense "operating costs" on a dollar-for-dollar basis, but are allowed to earn a "fair rate of return" on any capital investments included in their rate base. For inclusion in the rate base, an expenditure must be considered "used or useful" in providing services. 
decisions, regulatory policies affecting on-site expansion, and demand. Furthermore, options that allow for future buy-back of spent fuel, if desired (i.e., reversibility), may increase utilities' willingness to participate. If there is too much flexibility and uncertainty, however--for example, concerning the future rate structure and level in the event of cost increases or political and regulatory changes -then utilities may accordingly reduce their demand because planning is difficult under such uncertainty.

\section{MAJOR FINANCING ALTERNATIVES}

Among the financing alternatives for providing AFR storage facilities are: complete government financing through Congressional appropriations; domestic private sector financing through a Congressionally authorized government revolving fund; complete private sector financing; foreign and private sector financing; and government responsibility for financing and ownership of nuclear fuel throughout the nuclear fuel cycle, allowing for lease of the fuel to the private sector for a fee based on full cost recovery.

\section{Congressional Appropriations}

Under the option of Congressional appropriations, the DOE assumes complete financing responsibility for AFR storage facilities. Control over decisions is exercised by the executive and the legislative branches, as follows.

First, the DOE must prepare a budget request to be reviewed by the Office of Management and Budget (OMB) in the Executive office of the President. The budget request must specify the total amount of funds necessary ("budget authority") as well as the pattern of expenditure for disbursement of the funds over the entire length of the program ("budget outlays").

If $O M B$ approves the request, it is included in $D^{\circ}$ 's annual federal budget and submitted to Congress for review and approval.

If Congress approves, OMB will apportion federal funds on a quarter-by-quarter basis. Any changes in the outlay schedule or amount will be subject to executive and legislative branch approval, 
and both branches will continue to exercise oversight authority regarding the apportionment of funds for specific AFR projects. The flexibility of the program is therefore limited by the strict requirements for government approval, over time.

Since the government borrows funds from the U.S. Treasury to finance the program initially, before fees are collected, current taxpayers and future ratepayers share the cost burden. Fees may either be combined for storage and disposal or may be collected separately for disposal only. They may be collected either at the time of power generation or fuel discharge, or later at the time of delivery to the AFR facility or repository. Since the government is the owner and provides the capital investment, utilities will most likely be allowed to expense the fees only as operating costs (dollar for dollar) rather than incorporate the fees in their rate base (to earn a return).

\section{Revolving Fund}

The government can establish a revolving fund that allows it to finance AFR storage and disposal facilities through private sector contributions, consisting of prepayments of a combined fee for AFR storage and disposal services. Control over decisions is exercised by the executive and legislative branches through oversight authority regarding the activities of the fund, and initially by the enactment of enabling legislation to establish the fund and to collect contributions from the private sector. To the extent that private sector contributions are not sufficient to cover costs, the fund is authorized to borrow from the U.S. Treasury at private capital market rates (Triple A rates), but not at low-interest government rates.

Under this option, ratepayers, not taxpayers, assume the cost burden. Because fees are likely to be prepaid, or paid early (e.g., at power generation), when they can contribute to the initial capital investment and construction costs, utilities may be allowed to include the fee payments in their rate bases (as a share of the capital investment) and therefore earn a return. 
Private Sector and Utility Funding

If the government decides not to assume funding responsibility for AFR storage and disposal facilities, either because of budgetary constraints, conflicting public policy objectives, Congressional opposition, or evidence of private sector willingness and capability for independent funding, then one or several private firms and utilities may attempt to raise capital in the private capital markets to fund private AFRs for storage or disposal or both. In this case, the executive and legislative branches would not exercise either budgetary or oversight authority regarding the size, timing, and cost of the facilities; however, federal, state, and local regulatory agencies would still have some control over the determination of siting and acceptance criteria.

Under this option, there could be separate fees for storage and disposal or for disposal only. Ratepayers would bear the cost burden and fees would probably be prepaid or collected early (e.g., at the time of power generation--to help finance the initial investment and construction). Accordingly, utilities might be allowed to incorporate fee payments in their rate bases.

Private Sector, Utility, and Foreign Sector Financing

As an alternative to exclusive U.S. private sector and utility financing, one or more U.S. firms and utilities may join with one or more foreign firms or foreign government agencies to raise capital in the private U.S. or international capital markets. As a condition for financial participation, it is possible that some foreign partners might expect to use the U.S. facilities for storage and disposal of their own domestic spent fuel. The U.S. executive and legislative branches would not be able to exercise budgetary or oversight authority over such privately funded ventures, but regulatory bodies might exercise some control over siting and the determination of acceptance criteria, especially in the case of foreign spent fuel. 
As with the option of U.S. private sector financing, ratepayers (domestic and foreign) $^{2}$ would bear the cost burden, and fees would likely be prepaid or collected early--to help finance initial investment and construction--allowing for possible inclusion of fee payments in utilities' rate bases.

Leasing of Nuclear FueI by the Government

The U.S. Government could retain exclusive ownership of nuclear fuel throughout the fuel cycle. Leased fuel would be provided by the government for a fee (for combined storage and disposal) based on full-cost recovery and would be subject to change, depending on changes in costs, demand, and political and regulatory policies. Liability and financial risk would be borne entirely by the government, which would exercise primary control over all decisions regarding costs, timing, budgeting, size, and acceptance criteria for AFR facilities.

Both taxpayers and ratepayers would share the cost burden, although initial investment and construction costs would be financed from the U.S. Treasury, since fees would probably be collected late (e.g., at the time of spent fuel delivery). Accordingly, fee payments would probably be "expensed" by utilities (dollar for dollar) rather than being incorporated in their rate bases.

Table 4.1 summarizes the major demand characteristics of each of the above five financing options, according to the categories developed in the first section of this chapter.

\section{LIKELY EFFECT OF MAJOR FINANCING OPTIONS ON DEMAND}

We have argued, in general, that the choice of financing options may affect the demand for government AFR services; we will now indicate, in particular, how the five major financing alternatives identified in the section above might affect demand.

\footnotetext{
${ }^{2}$ Except in the case of foreign government (taxpayer) contributions.
} 
Tab1e 4.1

CHARACTERISTICS OF MAJOR FINANCING OPTIONS THAT MAY AFFECT DEMAND

\begin{tabular}{|c|c|c|c|c|c|}
\hline Characteristics & $\begin{array}{l}\text { Congressional } \\
\text { Appropriations }\end{array}$ & Revolving Fund & $\begin{array}{l}\text { Private Sector \& } \\
\text { Utility Financing }\end{array}$ & $\begin{array}{l}\text { Private Sector, } \\
\text { Utility, \& Foreign } \\
\text { Sector Financing }\end{array}$ & $\begin{array}{l}\text { Leasing of Fuel } \\
\text { from the Government }\end{array}$ \\
\hline Decisionmaking control & $\begin{array}{l}\text { Federal executive } \\
\& \text { legislative } \\
\text { branch contro1 } \\
\& \text { oversight }\end{array}$ & $\begin{array}{l}\text { Federal executive } \\
\text { \& legis lative con- } \\
\text { trol \& oversight }\end{array}$ & $\begin{array}{l}\text { Private sector \& } \\
\text { utility control }\end{array}$ & $\begin{array}{l}\text { Private sector \& } \\
\text { utility contro1 }\end{array}$ & $\begin{array}{l}\text { Federal executive \& } \\
\text { legislative control } \\
\& \text { oversight }\end{array}$ \\
\hline $\begin{array}{l}\text { Distribution of cost } \\
\text { burden }\end{array}$ & $\begin{array}{l}\text { Taxpayers \& rate- } \\
\text { payers }\end{array}$ & Ratepayers & Ratepayers & Ratepayers & $\begin{array}{l}\text { Taxpayers \& rate- } \\
\text { payers }\end{array}$ \\
\hline $\begin{array}{l}\text { Separate or combined } \\
\text { fees }\end{array}$ & Combined & Combined & Separate & Separate & Combined \\
\hline Tine of collection & $\begin{array}{l}\text { Probably late (at } \\
\text { time of delivery) }\end{array}$ & $\begin{array}{l}\text { Probably early (at } \\
\text { time of power } \\
\text { generation) }\end{array}$ & $\begin{array}{l}\text { Probably early (at } \\
\text { time of power } \\
\text { generation) }\end{array}$ & $\begin{array}{l}\text { Probably early (at } \\
\text { time of power } \\
\text { generation) }\end{array}$ & $\begin{array}{l}\text { Probably late (at } \\
\text { time of delivery) }\end{array}$ \\
\hline $\begin{array}{l}\text { Cost recovery by } \\
\text { utilities }\end{array}$ & $\begin{array}{l}\text { Fee payments ex- } \\
\text { pensed, not allowed } \\
\text { in rate base }\end{array}$ & $\begin{array}{l}\text { Fee may possibly } \\
\text { be allowed in } \\
\text { rate base }\end{array}$ & $\begin{array}{l}\text { Tee may possibly be } \\
\text { allowed in rate } \\
\text { base }\end{array}$ & $\begin{array}{l}\text { Fee may possibly be } \\
\text { allowed in rate } \\
\text { base }\end{array}$ & $\begin{array}{l}\text { Fee payments ex- } \\
\text { pensed, not allowed } \\
\text { in rate base }\end{array}$ \\
\hline Financing source & U.S. Treasury & $\begin{array}{l}\text { Private capital } \\
\text { markets and U.S. } \\
\text { Treasury--at pri- } \\
\text { vate market rates }\end{array}$ & $\begin{array}{l}\text { Private capital } \\
\text { markets }\end{array}$ & $\begin{array}{l}\text { Private \& foreign } \\
\text { capital markets }\end{array}$ & U.S. Treasury \\
\hline $\begin{array}{l}\text { Degree of Elexibility } \\
\& \text { reversibility }\end{array}$ & $\begin{array}{l}\text { Limited--due to } \\
\text { government budg- } \\
\text { etary \& oversight } \\
\text { control }\end{array}$ & $\begin{array}{l}\text { Fairly limited-- } \\
\text { due to government } \\
\text { oversight author- } \\
\text { ity }\end{array}$ & Falrly flexible & Fairly flexible & $\begin{array}{l}\text { Very limited--due } \\
\text { to exclusive govern- } \\
\text { ment ownership of } \\
\text { fuel }\end{array}$ \\
\hline
\end{tabular}


Table 4.2 presents a qualitative ranking of the effect that each demand characteristic-described in the previous two sections and summarized in Table 4.1--might have on the demand of domestic U.S. utilities for government AFR services. The rankings consist of high $(H)$, medium $(M)$, and low $(L)$, representing our qualitative evaluation of the 1ikely strength of the positive demand response--based on reasoning explained below.

\section{Congressiona1 Appropriations}

The demand response is likely to be favorably affected by the distribution of the cost burden-mecause taxpayers bear some of the burden; by the time of collection--because it is likely to be late (at time of delivery), thus allowing utilities to avoid the negative cash flow problems associated with early payments; and by the financing source--because by borrowing at U.S. Treasury rates, the financing costs should be less than by borrowing at private rates.

However, demand is likely to be negatively affected by the oversight and budgetary control of the government--preventing utilities from exerting much influence; by the restriction that fees for storage and disposal be combined--limiting utilities' choices about the size and timing of their own on-site storage expansion plans; by the treatment of fee payments as "operating expenses" rather than as capital investments--thus preventing utilities from including the payments in their rate bases and earning a return; and by limited flexibility and reversibility--owing to the degree of government control over decisionmaking and the restriction of choice from combined fees.

\section{Revolving Fund}

The utilities" demand response is likely to be favorably affected under a revolving fund option by the treatment of fee payments as capital investments to be included in the rate base, because utilities may then earn a return. However, demand is likely to be less favorably affected by governmental control over decisionmaking, which restricts utilities' influence; by the financing source-the U.S. Treasury--which may permit easier access than private capital 
Table 4.2

LIKELY IMPACT OF ALTERNATIVE FINANCING OPTIONS ON DEMAND

\begin{tabular}{|c|c|c|c|c|c|}
\hline Characteristics & $\begin{array}{l}\text { Congressiona1 } \\
\text { Appropriations }\end{array}$ & Revolving Fund & $\begin{array}{l}\text { Private Sector \& } \\
\text { Utility Financing }\end{array}$ & $\begin{array}{l}\text { Private Sector, } \\
\text { Utility, \& Foreign } \\
\text { Sector Financing }\end{array}$ & $\begin{array}{l}\text { Leasing of Fuel } \\
\text { from Government }\end{array}$ \\
\hline Decisionmaking control & L & $\mathrm{L}-\mathrm{M}$ & $\mathrm{H}$ & $\mathrm{H}$ & L \\
\hline $\begin{array}{l}\text { Distribution of cost } \\
\text { burden }\end{array}$ & $\mathrm{H}$ & $\mathrm{L}$ & $\mathbf{I}_{\mathbf{s}}$ & $M$ & $\mathrm{H}$ \\
\hline $\begin{array}{l}\text { Separate or combined } \\
\text { fees }\end{array}$ & $\mathbb{L}$ & L & $\mathrm{H}$ & H & $\mathrm{H}$ \\
\hline Time of collection & $\mathrm{H}$ & L & $\mathbf{L}$ & $\mathbf{L}$ & H \\
\hline $\begin{array}{l}\text { Cost recovery by } \\
\text { utilities }\end{array}$ & $\mathbf{L}$ & $\mathrm{H}$ & $\mathrm{H}$ & $\mathrm{H}$ & $\mathbf{L}$ \\
\hline Financing source & H & $\mathrm{L}-\mathrm{M}$ & L & L & $\mathrm{H}$ \\
\hline $\begin{array}{l}\text { Degree of flexibility } \\
\text { \& reversibility }\end{array}$ & $\mathbf{L}$ & $L-M$ & $\mathrm{H}$ & M & $\mathbf{L}$ \\
\hline
\end{tabular}

NoTE: $\mathbb{H}=$ high, $M=$ moderate, $\mathrm{L}=1 \mathrm{ow}$. 
markets, but will still be more expensive than Congressional appropriations, since the Treasury lends funds at private market rates; and by the limited degree of flexibility and reversibility, which is expected to be greater than under Congressional appropriations but less than under private sector financing.

The demand response is 1ikely to be negatively affected by the distribution of the cost burden, because it is borne entirely by ratepayers instead of being shared with taxpayers; by the restriction of combined fees, which limits choices among on-site expansion opportunities; and by the early collection of fees (probably at the time of power generation), which may create negative cash flow problems for the utilities.

\section{Private Sector Financing}

Under private sector financing, the demand response is 1 ikely to be positively affected by the greater control over decisionmaking; by the greater range of choice afforded by separate fees for storage or disposal; by the possibility of including fee payments in the rate base, thus earning a return; and by the greater flexibility and reversibility than are possible under government controlled and financed options.

However, demand is likely to be negatively affected by the distribution of the cost burden, which is borne entirely by ratepayers and not shared with taxpayers; by the early collection of fees, which may create negative cash flow problems for some utilities; and by the financing source--private capital markets--which impose higher rates than the U.S. Treasury, for example, under the Congressional appropriations option.

Private Sector, Utility, and Foreign Sector Financing

The demand response under the private sector, utility, and foreign sector financing option is likely to be very similar to that under strictly U.S. private sector and utility financing. However, U.S. utilities" demand may be higher under this option to the extent that the cost burden is shared with foreign ratepayers and taxpayers; 
but it may be lower if foreign financial participation imposes restrictions on acceptance criteria, size, timing, location, and types of facilities.

\section{Leasing of Fue1 from the Government}

Under the government leasing option, utilities would face a very restricted range of choices regarding government AFR storage and disposal facilities, because of the government's exclusive ownership of fuel. Assuming that the fees for storage and disposal are combined, demand would depend largely on a cost comparison between leasing the fuel and continuing to store it on-site, and paying the combined fee for selling it back to the government for storage and disposal. Because the government would always own the fuel, utilities would continue to incur leasing costs as long as they stored it on-site. Consequently, demand would probably be positively affected by AFR storage and disposal fees that were cheaper than cumulative leasing costs. In addition, demand would probably be positively affected by the sharing of the cost burden with taxpayers as well as ratepayers; by the late collection of fees (probably at time of delivery), allowing utilities to avoid the negative cash-flow problems associated with early payments; and by the financing source, the U.S. Treasury, which allows cheaper borrowing rates than under private sector financing (e.g., for on-site expansion or private AFR facilities). Demand may be negatively affected by the loss of control over spent fuel once it is returned to the government; by the treatment of fee payments as operating expenses, instead of capital investments that could be used to earn a return; and by the very restricted flexibility and reversibility once the fuel is delivered to government AFR storage and disposal facilities.

We hasten to emphasize that the demand response of utilities under each of these five financing options is subject to wide speculation, and the rankings in Table 4.2 represent only our qualitative assessment of the likely effects. More evidence and further analysis are necessary to determine more precisely the nature and extent of 
the utilities' demand response under these and other possible financing options. 
Chapter 5

ESTIMATING A RANGE OF DEMANDS FOR GOVERNMENT AFR'S

UNDER VARIOUS ASSUMPTIONS

In this chapter we estimate a range of demands for government AFR services under varying assumptions about costs, pricing policies, future events, financing arrangements, and future regulatory and political policies. In this way we hope to reconcile, or at least to provide insights into, the differences between conflicting demand studies that have been undertaken in the past. (For example, recall the discussion in Chap. 1, and Table 1.2, which illustrate the differences between the Stoller and NRDC demand projections.)

Our assumptions are chosen to represent three scenarios: an "extreme" case of maximum demand for government AFRs storage; a base case derived from current DOE estimates and expected future policies; 1 and an "extreme" case of minimum demand for government AFRs.

We begin by identifying the categories of assumptions that we use in defining the scenarios. Next, we define the scenarios by stating our assumptions explicitly for each category. We then estimate demand for each scenario. Finally, in Chap. 6, we attempt to explain the differences in demand projections under each scenario by identifying the critical parameters that can affect demand and the major groups that can influence the values of those parameters.

\section{CATEGORIES OF ASSUMPTIONS USED TO DEFINE ALTERNATIVE SCENARIOS}

To provide a representative range of scenarios, we begin by identifying four major categories of assumptions: demand, supply, pricing and financing, and regulatory and political policy assumptions. Each category includes:

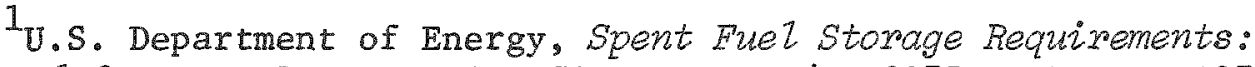
The Need for Away-From-Reactor Storage, DOE/ET-0075, February 1979.
} 
Demand assumptions about the likely future level and rate of demand for nuclear energy. This demand will determine the level and rate of accumulation of spent fuel (i.e., less or more than current DOE estimates) and the likely level of foreign demand for storage and/or disposal (for emergency returns, inadequate storage availability, and fuel assurance contracts).

- Supply assumptions about on-site expansion capabilities (considering maximum technical capabilities, realistic practical capabilities, and regulatory obstacles and costs); the timing and availability of government AFRs (in view of possible delays in construction and licensing); relative costs (degree of uncertainty about costs of on-site expansion and private AFRs relative to the fee); and transshipments (extent to which intra-utility transfers of spent fuel are allowed) and extent of availability of shipping casks.

- Pricing and financing assumptions about the nature of the fee (whether future changes in costs are to be reflected immediately, automatically and retroactively in the one-time fee, or are to be announced in advance); the regulatory treatment of the fee (extent of cost recovery allowed, rate of amortization allowed, and whether a tax-deductible advance operating account is allowed); whether the fee consists of separate or combined fees for storage and disposal or for disposal only; and whether or not future costs are expected to increase, remain as predicted, or fall. Assumptions are also made about the method and source of financing for government AFRs (government, private, or foreign sector financing).

- Regulatory and political policy assumptions about future decisions about commercial reprocessing and the breeder reactor program (indefinite delays, deferment until specified date, or acceleration) 
and possible new regulatory restrictions imposed for future nuclear reactors (requiring adequate on-site provision for lifetime storage needs prior to licensing).

In each category we choose specific assumptions to define the three demand scenarios, which range from an extreme case of maximum demand for government AFRs (Scenario 1) to an extreme case of minimum demand (Scenario 2) to a base case derived from current DoE estimates and expected future policies (Scenario 3). ${ }^{2}$ Table 5.1 describes the specific assumptions we have chosen to define each scenario.

\section{QUANTIFYING THE SCENARIOS}

On the basis of the assumptions specified in Table 5.1, we estimate the sensitivity of demand to changes in these assumptions, from one scenario to another, using Spent Fuel Storage Requirements: The Need for Away-From-Reactor Storage, DOE/ET-0075, as a base case. That report assessed the sensitivity of AFR demand to fuel burnup, reactor capacity factor, transshipment, discharge capability (e.g., full core reserve), and on-site expansion. For our estimates we begin with the DOE base case but allow only the level of transshipment and on-site expansions to vary as a function of the economic, regulatory, and political assumptions of Table 5.1. In the following sections we describe how the assumptions of Table 5.1 are used to generate AFR demand estimates for each scenario. Figures 5.1 and 5.2 illustrate the resulting demand projections for domestic utilities and for domestic plus foreign sources.

Scenario I: Maximum Demand for Government AFR Storage Assumptions

Scenario I represents conditions under which the domestic and foreign demand for government AFR storage facilities is the greatest. To do so, it is assumed that only one-half of all planned on-site expansions are completed and that the level of foreign demand is

\footnotetext{
${ }^{2}$ IbId.
} 
Table 5.1

NUCLEAR WASTE STORAGE AND DISPOSAL SCENARIOS AND ASSUMPTIONS

\begin{tabular}{|c|c|c|c|}
\hline & Scenario I & Seenamo II & Scentrio IIT \\
\hline Factor & $\begin{array}{l}\text { Maximum demand for } \\
\text { government AFR storage } \\
\text { and disposal. }\end{array}$ & $\begin{array}{l}\text { Minimum demand for gov- } \\
\text { ernment storage. Maxi- } \\
\text { mum private solutions } \\
\text { to storage problem, in- } \\
\text { cluding private AFRs. } \\
\text { Government provides for } \\
\text { disposal only. }\end{array}$ & $\begin{array}{l}\text { Base case: } \\
\text { Limited private initia- } \\
\text { tives for providing own } \\
\text { storage. Large demand } \\
\text { for government AFR } \\
\text { storage and disposal. }\end{array}$ \\
\hline \multicolumn{4}{|c|}{ DEHAND ASSUMPTIONS } \\
\hline $\begin{array}{l}\text { Demand for nuclear } \\
\text { energy }\end{array}$ & $\begin{array}{l}\text { Higher level and rate of } \\
\text { demand than current DoE } \\
\text { estimates (so that wastes } \\
\text { are accumulating more } \\
\text { rapidly than predicted). }\end{array}$ & $\begin{array}{l}\text { Lower level and rate of } \\
\text { demand than current DOE } \\
\text { estimates (so that } \\
\text { wastes are not accumu- } \\
\text { lating as rapidly as } \\
\text { predicted). }\end{array}$ & $\begin{array}{l}\text { Current DOE estimates of } \\
\text { denand ( } 1 . e . \text {. Reference Case, } \\
\text { from DoE report cited in } \\
\text { footnote (a). }\end{array}$ \\
\hline $\begin{array}{l}\text { Foreign demand for } \\
\text { government AFR } \\
\text { storage and dis- } \\
\text { posala }\end{array}$ & $\begin{array}{l}\text { Returns from countries } \\
\text { in sensitive regions and } \\
\text { from countries with in- } \\
\text { adequate storage and } \\
\text { disposal facillties } \\
\text { (countries with both } \\
\text { smal1 and medium-sized } \\
\text { nuclear power prograns)-- } \\
\text { DOE option } 3 \text {. }\end{array}$ & $\begin{array}{l}\text { Retums from countries } \\
\text { in sensitive reglons } \\
\text { only--DOE option } 1 .\end{array}$ & $\begin{array}{l}\text { Returns from countries in } \\
\text { sensitive regions and from } \\
\text { countries with inadequate } \\
\text { storage and disposal facili- } \\
\text { ties (smat nuctear power } \\
\text { programs only)-DoE option } 2 .\end{array}$ \\
\hline \multicolumn{4}{|c|}{ SUPELY ASSUMETIONS } \\
\hline $\begin{array}{l}\text { On-site utility } \\
\text { storage expansion }\end{array}$ & $\begin{array}{l}\text { Minimum expansion. As- } \\
\text { sumes that regulatory } \\
\text { policies of state PUCs, } \\
\text { NRC, and FERC make it } \\
\text { difficult to expand } \\
\text { (assumes only } 1 / 2 \text { of } \\
\text { planned expansions } \\
\text { are allowed). }\end{array}$ & $\begin{array}{l}\text { Maximum expansion, in- } \\
\text { cluding major new con- } \\
\text { struction and private } \\
\text { AERs (maximum compac- } \\
\text { tion). }\end{array}$ & $\begin{array}{l}\text { Limited on-site expansion } \\
\text { consisting of compacting, } \\
\text { reconfiguring, pooling, etc., } \\
\text { without major new construc- } \\
\text { tion (all planned on-site } \\
\text { expansions). }\end{array}$ \\
\hline $\begin{array}{l}\text { Timing and avail- } \\
\text { ability of govern- } \\
\text { ment AFrs (in view } \\
\text { of possible con- } \\
\text { struction delays, } \\
\text { supply bottlenecks, } \\
\text { licensing problems, } \\
\text { etc.) }\end{array}$ & $\begin{array}{l}\text { Little uncertaincy } \\
\text { about government AFRs, } \\
\text { but major uncertainty } \\
\text { about on-site expan- } \\
\text { sion. }\end{array}$ & $\begin{array}{l}\text { Major uncertainty about } \\
\text { government AFR storage } \\
\text { and disposal facility } \\
\text { schedule. }\end{array}$ & Major uncertainty. \\
\hline Relative costs & $\begin{array}{l}\text { Major uncertainty about } \\
\text { relative costs of on- } \\
\text { site expansion but } \\
\text { little uncertainty about } \\
\text { government AFR fees. }\end{array}$ & $\begin{array}{l}\text { Major uncertainty about } \\
\text { government AFR costs } \\
\text { but little uncertainty } \\
\text { about costs of on-site } \\
\text { expansion and private } \\
\text { AFRs. }\end{array}$ & $\begin{array}{l}\text { Major uncertainty about } \\
\text { all relative costs, espe- } \\
\text { cially about disposal costs. }\end{array}$ \\
\hline Transshipments & No transshipments. & $\begin{array}{l}\text { A11 intrautility } \\
\text { transshipments. }\end{array}$ & $\begin{array}{l}1 / 2 \text { of intrautility ship- } \\
\text { ments are made. }\end{array}$ \\
\hline
\end{tabular}

For footnotes, see end of table on following page. 
Table 5.1--continued

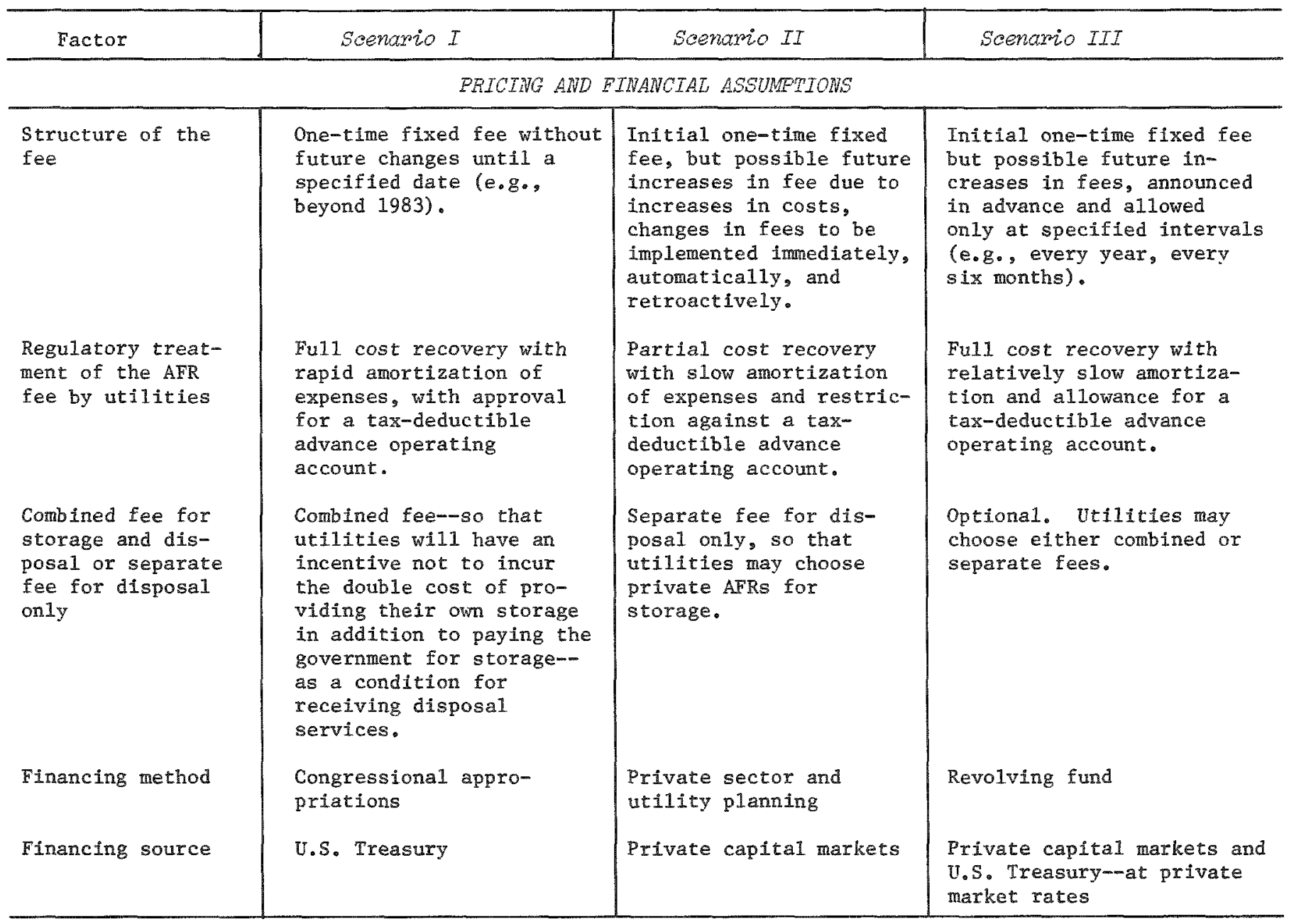

REGULATORY AND POLITICAL POLICY ASSUMPIONS

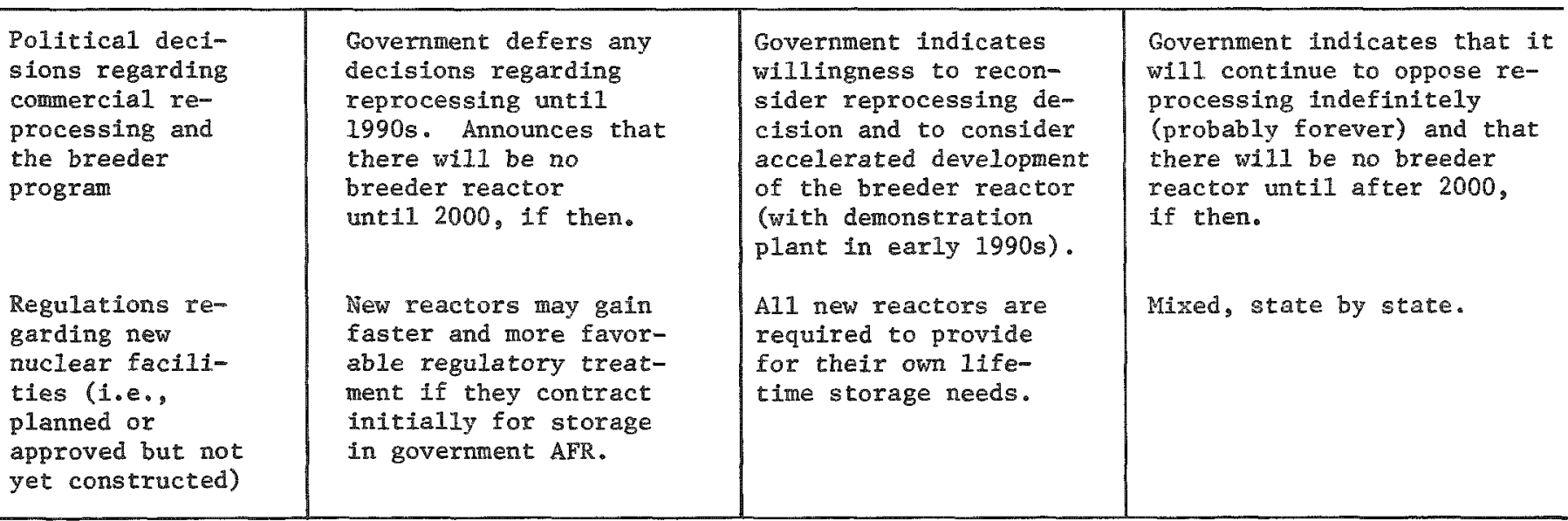

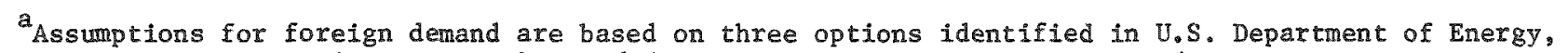
Spent Fuel Storage Requirements: The Need for Away-From-Reactor Storage, DoE/ET-0075, February 1979. 


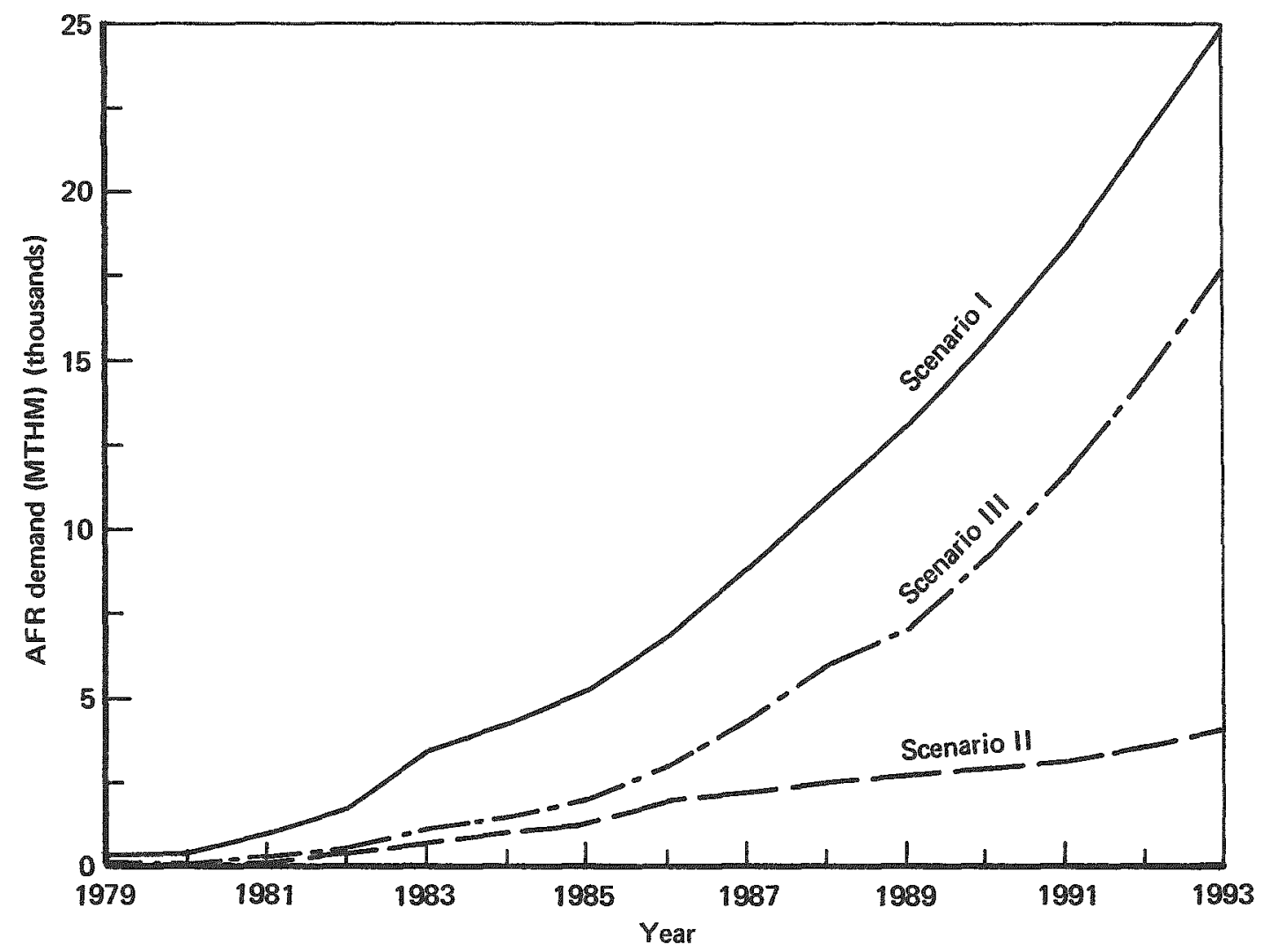

Fig. 5.1-AFR demand estimates for domestic participation

equal to DOE Option 3 (see Table 3.1). Assuming that only one-half of planned on-site expansions are completed suggests two circumstances:

- DOE relaxes spent fuel storage acceptance criteria to permit utilities that have not reracked to use the AFR;

- Legislative opposition constrains on-site expansion of storage capabilities in many states.

If states were to oppose on-site expansion, they would probably also oppose transshipment of spent fuel to relieve storage problems. We assume, however, that the added effect of no transshipment is insignificant in combination with the level of expansions allowed. To verify this, the Stoller DISFU Model would have to be used. 


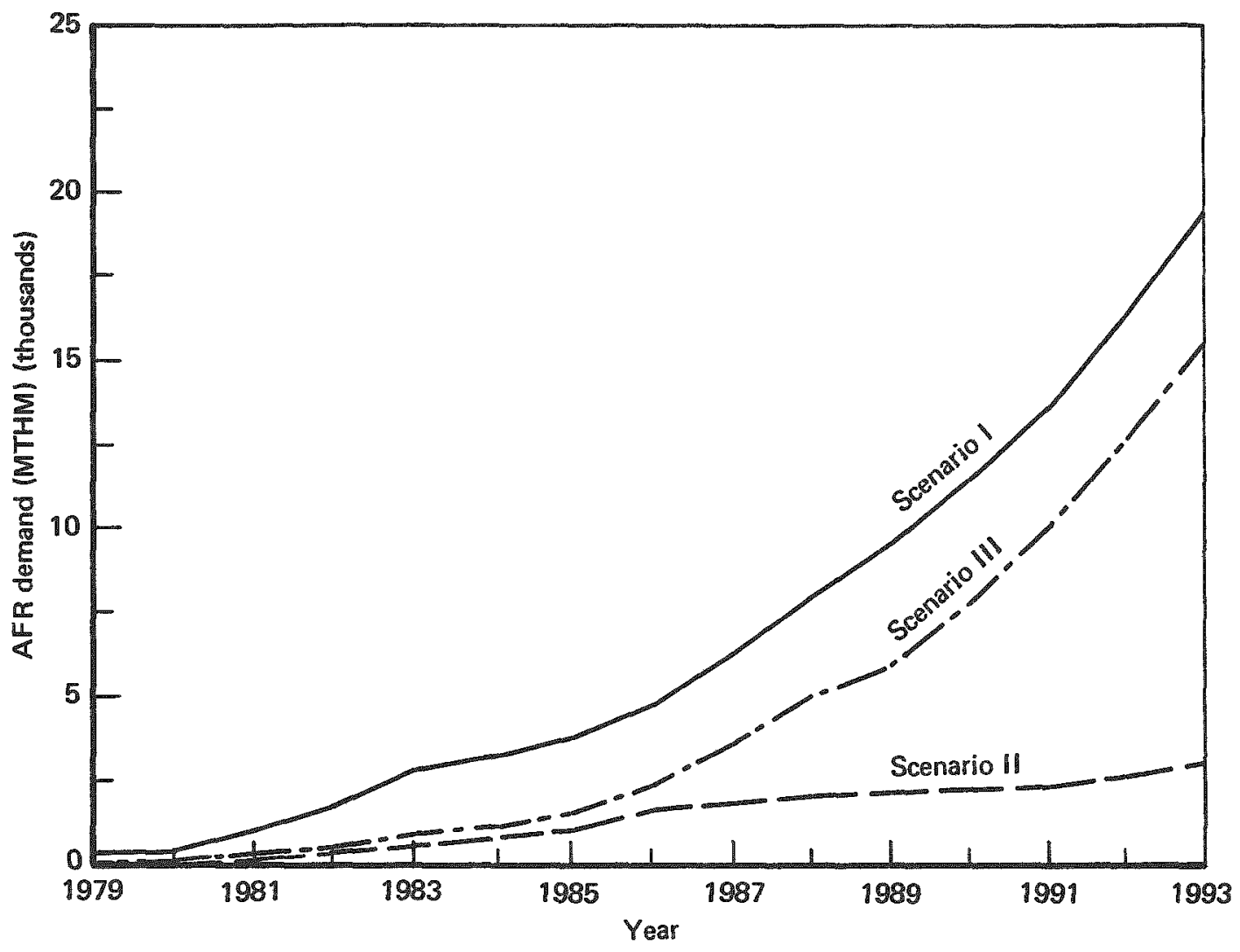

Fig. 5.2-AFR demand estimates for domestic and foreign participation

Scenario II: Minimum Demand for AFR

Scenario II represents conditions under which the domestic and foreign demand for AFR storage is minimized owing to utilities taking maximum responsibility for their own storage needs and to restrictions on the acceptance of foreign fuel. For domestic utilities, the DOE base case is used with some distributed private AFRs (1000 to 2000 MTHM) built to service NERC regions (or large utilities or consortia). Foreign demand is based on DOE Option 1 (see Table 3.1), which involves transfers from countries in sensitive regions.

We assume the DOE base case as a starting point because the maximum on-site expansion would be uneconomic relative to distributed AFRs (recall the discussion of relative costs in Chap. 2). Although we cannot estimate the demand from this option in detail without a model such as DISFUL, we assume that distributed AFRs would not be available before at least 1985, after which time demand for a central 
facility would fall drastically. A private facility would be unlikely to handle foreign fuel. We allow for the possibility of a resumption of reprocessing. Although we do not know how much this might reduce the total demand for storage, we believe that it will increase the demand for on-site storage or storage at private AFRs relative to government AFRs, because of the utilities' greater access to and control over their spent fuel under these options.

\section{Scenario III: Base Case}

In Scenario III we alter the DOE base case by assuming that only one-half of all intrautility transshipments take place. Foreign demand is set by DOE Option 2 (see Table 3.1)--involving acceptance of foreign fuel from sensitive regions and from countries where there are immediate storage problems--and nonproliferation benefits to be realized.

For domestic AFR demand, DOE's base case provides the starting point. However, whereas DOE assumes transshipments would occur between reactors owned by the same utility, shipping cask availability and state legislation could hamper these measures. Consequently, we assume that only one-half of the intrautility transshipments occur.

As is evident from Figs. 5.1 and 5.2, estimated demand under the three scenarios ranges very dramatically from less than 2500 MTHM to more than 20,000 MTHM by 1993 (an eight-fold difference) for domestic participation, and from less than 5000 MTHM to more than 25,000 MTHM by 1993 (a five-fold difference) for both domestic and foreign participation. This implies that the number of government AFRs (of size 5000 MTHM) required to satisfy demand ranges from five under Scenario I to only one under Scenario II. If we assume that the capital costs of each AFR are approximately \$225 million in 1979 dollars, that operating costs are $\$ 5$ million/year, and that, under scenario $I$, AFRs are built in 1981, 1983, 1985, 1987, and 1989 and under Scenario II, one AFR is built in 1983, then the present discounted value of the difference in total costs (discounted at a rate of 8 percent) in 1979 dollars, is $\$ 690$ million (that is, $\$ 890$ million for Scenario I minus $\$ 200$ million 
for Scenario II). 3 This amount may appear small compared with the cumulative billions of dollars of capital investment in the nuclear industry (e.g., the current estimated capital cost of constructing a single 1000 megawatt nuclear power plant exceeds one billion dollars). However, this amount appears quite sizeable when considered in terms of the transfer of dollars between the private and government sector. Depending on how and how quickly the transfer is accomplished (recall the discussion of alternate financing methods in Chap. 4), the difference in the magnitude and timing of government capital expenditures under Scenarios I or II could have noticeably different impacts on capital markets, cash flows within utilities, and the distribution of storage costs between taxpayers and ratepayers.

Having identified the differences in predicted demand among our three scenarios, we explore in Chap. 6 some of the reasons for these differences.

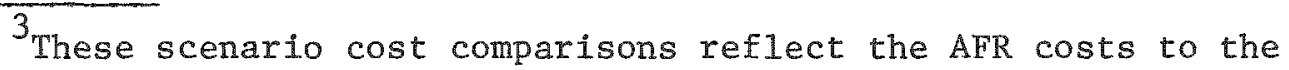
government and do not reflect total storage costs, including private storage costs, which also vary across scenarios, and transportation costs. For a more complete comparison with total storage costs, see Savannah River Laboratory, Storage Cost for Spent Power Reactor Fuel, DPST-AFR-79-100, January 1979. 
Chapter 6

EXPLAINING THE DIFFERENCE IN DEMAND PROJECTIONS

To the extent possible, this chapter explains the difference in AFR demand projections between scenarios, and in doing so, highlights the policy options that DOE and other agencies may take to support or constrain realization of each scenario. We begin by identifying the important assumptions, or critical parameters, that can affect the magnitude, intensity, and timing of demand for government AFRs. We then identify those government agencies and other groups that can affect the values of these critical parameters. Finally, we identify actions that DOE would have to undertake to achieve each scenario, and highlight policies and activities of other agencies or groups that could either support or oppose DOE's actions.

\section{CRITICAL PARAMETERS AND ASSUMPTIONS}

Among the numerous assumptions specified in Table 5.1, nine are of critical importance in explaining differences in the magnitude, intensity, and timing of demand for government AFRs. These nine critical parameters represent specific examples of the demand factors that we identified in Chaps. 3 and 4. They include:

1. Regulatory treatment of the fee,

2. Total U.S. demand for nuclear energy,

3. The timing and nature of government legislation, regulation, and policies affecting spent fuel reprocessing and the breeder program,

4. The extent of regulations regarding on-site expansion of spent fuel storage pools and the licensing of decentralized, privately and/or utility financed AFRs,

5. Timing and availability of government AFRs and repositories,

6. The extent to which transshipment of spent fuel is 
allowed from a reactor that has filled its storage basin to one that has excess storage space,

7. The availability of shipping casks for transshipments and/or transfers to AFRs,

8. Foreign demand for U.S. government operated AFRs, and

9. How and by whom the AFR storage facilities are financed.

Each of these parameters affects the level of demand for government AFRs to varying degrees. Table 6.1 summarizes the extent to which each critical parameter affects AFR demand. We compare the impact on demand for both the short run (through the year 1984) and the long run (through the year 2000). Those critical parameters most influential in affecting AFR demand in the short run are:

- The extent to which transshipment of spent fuel between reactors is permitted, and

- The extent to which on-site storage expansion is permitted. (There is increasing sentiment, as demonstrated by state regulatory action, both to limit expansion of on-site storage capacity and to prevent the storage of out-ofmstate spent fuel.)

In the long run, however, these two parameters are far less influential than are decisions regarding reprocessing and the breeder reactor program, and government AFR availability.

Demand for nuclear energy is not expected to influence AFR demand strongly in either the short or the long run. The reason is that licensing of a new reactor could be made contingent upon its having enough on-site storage to accommodate 40 years of spent fuel. A further contingency could be added that might require excess onsite storage capacity so that nearby reactors could transship spent fuel.

Recognizing that each of the eight parameters affects the level of demand for government AFRs to varying degrees over time, we have defined our three scenarios (outlined in Table 5.1) to represent very 
Table 6.1

EXTENT TO WHICH EACH CRITICAL PARAMETER AFFECTS

THE DEMAND FOR GOVERNMENT AFR'S

\begin{tabular}{|c|c|c|}
\hline \multirow[b]{2}{*}{ Critical Parameter } & \multicolumn{2}{|c|}{$\begin{array}{l}\text { Sensitivity of } \\
\text { AFR Demand to Changes } \\
\text { in Critical Parameters }\end{array}$} \\
\hline & $\begin{array}{l}\text { Short Rum } \\
\text { (Through 1984) }\end{array}$ & $\begin{array}{l}\text { Long Run } \\
\text { (Through 2000) }\end{array}$ \\
\hline $\begin{array}{l}\text { Regulatory treatment of the fee } \\
\text { Demand for nuclear energy } \\
\text { Reprocessing and the LMFBR } \\
\text { On-site pool expansion } \\
\text { Government AFR availability } \\
\text { Transshipment } \\
\text { Shipping cask availability } \\
\text { Foreign demand for AFRs } \\
\text { How and by whom the AFR } \\
\text { facilities are financed }\end{array}$ & $\begin{array}{l}\text { Moderate } \\
\text { Low } \\
\text { Low } \\
\text { High } \\
\text { Moderate } \\
\text { High } \\
\text { Moderate } \\
\text { Moderate }\end{array}$ & $\begin{array}{l}\text { Moderate } \\
\text { Low } \\
\text { High } \\
\text { High } \\
\text { High } \\
\text { Low } \\
\text { Low to moderate } \\
\text { Low } \\
\text { Moderate }\end{array}$ \\
\hline
\end{tabular}

different assumptions regarding these parameters. Table 6.2 summarizes how each of the three scenarios treats these parameters.

GROUPS WITH POWER TO AFFECT THE VALUES OF CRITICAL PARAMETERS

Table 6.3 compares the extent to which various government agencies and public groups can influence the values of these critical parameters. Comparing Table 6.3 with Table 6.1 indicates how each group could influence AFR demand (as will be explained in the next section below).

The Department of Energy could influence AFR demand by setting

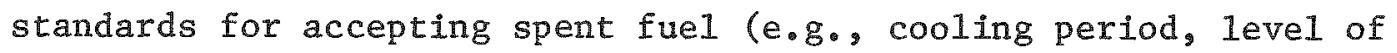
on-site expansion, efforts to transship fuel) and by setting the fee structure for spent fuel transfers. DOE can influence shipping cask availability through $R \& D$ support. In addition, although future decisions about reprocessing and the LMFBR will be made at the White House and in Congress, they are influenced by technical and institutional developments that DOE may undertake. In conjunction with 
Table 6.2

ASSUMPTIONS FOR CRITICAL PARAMETERS

OF THE THREE SCENARIOS

\begin{tabular}{|c|c|c|c|}
\hline Critical Parameter & $\begin{array}{l}\text { Scenario I, } \\
\text { Maximum } \\
\text { AFR Demand }\end{array}$ & $\begin{array}{l}\text { Scenario II, } \\
\text { Minimum } \\
\text { AFR Demand }\end{array}$ & $\begin{array}{l}\text { Scenario III, } \\
\text { Base Case }\end{array}$ \\
\hline $\begin{array}{l}\text { Regulatory treatment } \\
\text { of the fee }\end{array}$ & $\begin{array}{l}\text { Ful1 cost } \\
\text { recovery }\end{array}$ & $\begin{array}{l}\text { Partial cost } \\
\text { recovery }\end{array}$ & $\begin{array}{l}\text { Ful1 cost } \\
\text { recovery }\end{array}$ \\
\hline $\begin{array}{l}\text { Demand for nuclear } \\
\text { energy }\end{array}$ & $\begin{array}{l}\text { Higher than } \\
\text { current DOE } \\
\text { estimates }\end{array}$ & $\begin{array}{l}\text { Lower than } \\
\text { current DOE } \\
\text { estimates }\end{array}$ & $\begin{array}{l}\text { Current DOE } \\
\text { estimates (see } \\
\text { DOE/ET-0075) }\end{array}$ \\
\hline $\begin{array}{l}\text { Assumptions regarding } \\
\text { reprocessing and } \\
\text { the LMFBR }\end{array}$ & $\begin{array}{l}\text { Decisions } \\
\text { deferred }\end{array}$ & $\begin{array}{l}\text { Strong } \\
\text { possibility }\end{array}$ & $\begin{array}{l}\text { No reprocessing } \\
\text { in near term }\end{array}$ \\
\hline $\begin{array}{l}\text { Assumptions regarding } \\
\text { on-site pool } \\
\text { expansion }\end{array}$ & $\begin{array}{l}\text { Minimum-- } \\
\text { only one-half } \\
\text { of planned } \\
\text { expansion }\end{array}$ & $\begin{array}{l}\text { Maximum-- } \\
\text { more than } \\
\text { currently } \\
\text { planned }\end{array}$ & $\begin{array}{l}\text { Current } 1 y \\
\text { planned }\end{array}$ \\
\hline $\begin{array}{l}\text { Availability of } \\
\text { government AFRs }\end{array}$ & High & Low & Medium \\
\hline $\begin{array}{l}\text { Extent to which } \\
\text { transshipment is } \\
\text { assumed permitted }\end{array}$ & $\begin{array}{l}\text { None } \\
\text { allowed }\end{array}$ & Maximum & $\begin{array}{l}\text { One-half of } \\
\text { maximum }\end{array}$ \\
\hline $\begin{array}{l}\text { Availability of } \\
\text { shipping casks }\end{array}$ & Sufficient & Sufficient & Sufficient \\
\hline $\begin{array}{l}\text { Extent of foreign } \\
\text { demand for AFRs }\end{array}$ & DOE Option 3 & DOE Option 1 & DOE Option 2 \\
\hline $\begin{array}{l}\text { How and by whom the } \\
\text { AFR facilities } \\
\text { are financed }\end{array}$ & $\begin{array}{l}\text { Congressional } \\
\text { appropriation }\end{array}$ & $\begin{array}{l}\text { Private } \\
\text { sector and } \\
\text { utility } \\
\text { financing }\end{array}$ & Revolving fund \\
\hline
\end{tabular}


Table 6.3

EXTENT OF INFLUENCE VARIOUS GROUPS HAVE ON CRITICAL PARAMETERS

\begin{tabular}{|c|c|c|c|c|c|c|c|c|}
\hline \multirow[b]{2}{*}{ Group } & \multicolumn{8}{|c|}{ Critical Parameter } \\
\hline & $\begin{array}{l}\text { Fee Setting and } \\
\text { Government AFR } \\
\text { Availability }\end{array}$ & $\begin{array}{l}\text { Demand } \\
\text { for } \\
\text { Nuclear } \\
\text { Energy }\end{array}$ & $\begin{array}{l}\text { Reproces- } \\
\text { sing and } \\
\text { LMFBR }\end{array}$ & $\begin{array}{l}\text { On-Site } \\
\text { Expansion }\end{array}$ & $\begin{array}{l}\text { Trans- } \\
\text { shipment }\end{array}$ & $\begin{array}{c}\text { Shipping } \\
\text { Cask } \\
\text { Availability }\end{array}$ & $\begin{array}{l}\text { Foreign } \\
\text { Demand } \\
\text { for AFRs }\end{array}$ & $\begin{array}{l}\text { Financing } \\
\text { Arrangements }\end{array}$ \\
\hline DOE & $\mathrm{H}$ & M & M & $\mathrm{H}$ & M & M & M & $\mathrm{H}$ \\
\hline NRC & $\mathrm{H}$ & M & H & H & $\mathrm{H}$ & M & $\mathrm{L}$ & $\mathrm{L}$ \\
\hline EPA & $\mathrm{H}$ & $\mathrm{M}$ & M & M & $\mathrm{H}$ & $\mathbf{L}$ & $\mathbf{L}$ & $\mathbf{L}$ \\
\hline $\begin{array}{l}\text { State PUCs and other } \\
\text { state agencies }\end{array}$ & H & $\mathrm{H}$ & M & $\mathrm{H}$ & $\mathrm{H}$ & $\mathrm{L}$ & $\mathrm{L}$ & $\mathrm{H}$ \\
\hline Utilities & $\mathrm{L}$ & $\mathrm{H}$ & $\mathrm{M}$ & M & $\mathrm{H}$ & $\mathrm{L}$ & $\mathrm{L}$ & H \\
\hline Intervenor groups & $\mathrm{M}$ & $\mathbf{M}$ & M & $\mathrm{M}$ & $\mathrm{H}$ & $\mathrm{L}$ & $\mathrm{L}$ & $\mathrm{L}$ \\
\hline Congress & $\mathrm{H}$ & $\mathbb{M}$ & $\mathrm{H}$ & $\mathrm{L}$ & $\mathbf{L}$ & $\mathbf{L}$ & M & $\mathrm{H}$ \\
\hline State Department & $\mathrm{L}$ & $\mathrm{L}$ & $L$ & I & $\mathbf{L}$ & $\mathrm{L}$ & $\mathrm{H}$ & $\mathrm{L}$ \\
\hline $\begin{array}{l}\text { Department of } \\
\text { Transportation }\end{array}$ & $\tau$ & $\mathrm{L}$ & $\mathrm{L}$ & $\mathrm{L}$ & $\mathrm{H}$ & L & $\mathrm{L}$ & L \\
\hline $\begin{array}{l}\text { Private nuclear } \\
\text { industry }\end{array}$ & $L$ & $M$ & $\mathrm{M}$ & $M$ & L & $\mathrm{H}$ & $\mathrm{L}$ & $\mathrm{H}$ \\
\hline
\end{tabular}

NOTE: $\mathrm{H}=$ high, $M=$ moderate, $\mathrm{L}=$ low. 
the State Department, DOE also determines the criteria for accepting foreign spent fuel and thus influences the potential for foreign participation.

The NRC could influence AFR demand and the conduct of spent fuel storage and disposal policies through regulation of facilities and procedures. NRC has direct authority over expansions of on-site storage capacity and transshipment of spent fuel. Through its regulation of shipping cask designs, the Commission influences cask availability, because delays or changes in cask-design criteria impede the production of casks by private industry.

The Environmental Protection Agency (EPA) and the Department of Transportation (DOT) play similar roles to that of the NRC in that their authority to set environmental and transportation standards can affect the capacity to expand on-site storage, transfer spent fuel, and operate AFRs.

State PUCs and other state regulatory agencies affect AFR demand by ruling on the financial disposition within utilities of the one-time fee. Also, some regulatory bodies (including state legislatures) may influence AFR demand by denying on-site storage expansion, transshipments, or storage of spent fuel generated in other states.

Utilities have the most direct effect on AFR demand in the short term through their efforts to transship spent fuel and to expand their on-site capacities, and in the long term by efforts to participate in private decentralized AFRs.

Intervenor groups pressing their causes related to nuclear power can influence any of the critical parameters associated with regulation. They often delay decisions and hence add to uncertainties regarding, for example, on-site expansions, transshipments of spent fuel, and AFR siting.

Congress directly influences the conduct of spent fuel storage policy through its power to approve funding and legislative authority for an AFR. Consequently, the availability of a government AFR is largely a matter for Congress to determine. 
THE EXTENT TO WHICH EACH GROUP CAN INFLUENCE AFR DEMAND

By convoluting Tables 6.1 and 6.3, we obtain Table 6.4, which indicates the extent to which government, public, and private groups can influence $A F R$ demand in both the short run and the long run.

In the short run the most influential groups would be the regulatory bodies--NRC, EPA, and state regulatory bodies--because their regulation could immediately affect on-site expansion. Utilities, as well, would clearly be influential in the short run, whereas Congress could have a significant effect in the long run through its funding powers.

By setting criteria for accepting spent fuel (e.g., cooling period, extent of storage expansion) DOE can substantially affect AFR demand in both the short run and the long run.

ACTIONS AND POLICIES THAT SUPPORT OR OPPOSE EACH SCENARIO

Each of the three scenarios discussed Chap. 4 implies a specific spent fuel disposition policy. DOE can pursue each policy by specifying the appropriate fee structure, setting requirements for spent

Table 6.4

EXTENT TO WHICH GOVERNMENT, PUBLIC, AND

PRIVATE GROUPS CAN AFFECT AFR DEMAND

\begin{tabular}{l|c|c}
\hline \multirow{2}{*}{\multicolumn{1}{c|}{ Group }} & \multicolumn{2}{|c}{ Effect on AFR Demand } \\
\cline { 2 - 3 } & $\begin{array}{c}\text { Short Run } \\
\text { (Through 1984) }\end{array}$ & $\begin{array}{c}\text { Long Run } \\
\text { (Through 2000) }\end{array}$ \\
\hline DOE & $\mathrm{H}$ & $\mathrm{H}$ \\
NRC & $\mathrm{H}$ & $\mathrm{H}$ \\
ERA & $\mathrm{H}$ & $\mathrm{H}$ \\
State PUCs & $\mathrm{H}$ & $\mathrm{H}$ \\
Utilities & $\mathrm{M}$ & $\mathrm{M}$ \\
Intervenor groups & $\mathrm{M}$ & $\mathrm{M}$ \\
Congress & $\mathrm{M}$ & $\mathrm{M}$ \\
State Department & $\mathrm{L}$ & $\mathrm{L}$ \\
Department of Transportation & $\mathrm{L}$ & $\mathrm{L}$ \\
Private industry & $\mathrm{M}$ & $\mathrm{M}$ \\
\hline
\end{tabular}

NOTE: $\quad H=$ high,$M=$ moderate, $L=10 \mathrm{w}$. 
fuel acceptance, and providing necessary storage facilities. Other agencies and groups may carry out actions that either support or oppose fulfillment of DOE's policy. Below, we specify the DOE actions associated with conducting each scenario, and in Table 6.5, we summarize the corresponding supporting and opposing actions of various other agencies and groups.

Scenario I represents the maximum demand for government AFR storage and disposal services, with the government taking an active role in relieving domestic storage problems. The scenario assumes an aggressive policy of pursuing foreign spent fuel storage. DOE would conduct this policy contingent upon Congressional support by setting lenient criteria for accepting spent fuel. These criteria may include a short cooling period (e.g., one year), no transshipment, and minimal reracking of storage pools. The fee structure would require the government to absorb the risk of future cost increases.

Scenario II represents the minimum demand for government AFR services by providing incentives for private solutions to storage problems, including private AFRs, but with the government assuming responsibility for disposal services. Any AFR storage capacity provided by the government would be limited to acceptance of foreign spent fuel only on an emergency need basis, and of domestic spent fuel only when insufficient storage space threatens reactor operations. The latter restriction places the burden upon utilities to pursue all possible private solutions to storage problems.

Scenario III assumes a significant government role in interim storage of spent fuel, with limited encouragement of private efforts. Foreign fuel would be accepted during emergencies and from countries with small nuclear power programs experiencing storage problems. To implement this policy, DOE should impose a fee structure that is not subject to drastic changes, accept fuel that has cooled for five years, and require utilities to rerack pools to the extent technically feasible. 
Table 6.5

ACTIONS THAT SUPPORT OR OPPOSE DOE'S IMPLEMENTATION OF THREE SCENARIOS

\begin{tabular}{|c|c|c|}
\hline Agency & Supporting Action & Opposing Action \\
\hline \multicolumn{3}{|c|}{ Scenario I } \\
\hline NRC & $\begin{array}{l}\text { Allow shipment of one-year cooled } \\
\text { fuel. Restrict transshipments. } \\
\text { Restrict pool expansions. Clarify } \\
\text { regulations for shipping casks. }\end{array}$ & $\begin{array}{l}\text { Deny licensing to government AFR. } \\
\text { Delay regulations on cask design. }\end{array}$ \\
\hline $\begin{array}{l}\text { State PUCs and } \\
\text { regulators }\end{array}$ & $\begin{array}{l}\text { Allow full pass-through of one-time } \\
\text { fee to utility customers. Deny } \\
\text { expansion of storage pools or } \\
\text { transshipments. }\end{array}$ & Deny full cost pass-through. \\
\hline Intervenors & & $\begin{array}{l}\text { Seek to require lifetime storage } \\
\text { of spent fuel at each reactor. } \\
\text { Seek to allow transportation to } \\
\text { repository only. }\end{array}$ \\
\hline Congress & $\begin{array}{l}\text { Provide full funding for AFR. } \\
\text { Pursue foreign participation. }\end{array}$ & $\begin{array}{l}\text { Deny AFR authorization and fund- } \\
\text { ing. }\end{array}$ \\
\hline Utilities & $\begin{array}{l}\text { Early comitment to participate } \\
\text { in AFR program. Advance payment } \\
\text { of fees. }\end{array}$ & $\begin{array}{l}\text { Delay decision to participate in } \\
\text { AFR program. }\end{array}$ \\
\hline \multicolumn{3}{|c|}{ Scenario II } \\
\hline NRC & $\begin{array}{l}\text { Permit on-site expansion: reracking } \\
\text { and volume expansion. Permit transm } \\
\text { shipments. Require lifetime storage } \\
\text { at new reactors. }\end{array}$ & $\begin{array}{l}\text { Restrict pool volume expansions. } \\
\text { Restrict transshipments. }\end{array}$ \\
\hline $\begin{array}{l}\text { State PUCs and } \\
\text { regulators }\end{array}$ & $\begin{array}{l}\text { Disallow full pass-through of } \\
\text { government fee. Permit on-site } \\
\text { expansions. }\end{array}$ & $\begin{array}{l}\text { Restrict on-site expansions, } \\
\text { transshipments, or storage of } \\
\text { out-of-state spent fuel. }\end{array}$ \\
\hline Utilities & $\begin{array}{l}\text { Actively pursue on-site expansion } \\
\text { and inter-and intrautility storage. }\end{array}$ & $\begin{array}{l}\text { Delay expansion efforts and pur- } \\
\text { suit of private solutions. }\end{array}$ \\
\hline Intervenors & $\begin{array}{l}\text { Require } 1 \text { ifetime storage of spent } \\
\text { fuel at reactors. }\end{array}$ & $\begin{array}{l}\text { Block expansion of pools or } \\
\text { transshipments. }\end{array}$ \\
\hline Congress & $\begin{array}{l}\text { Provide low funding level for modi- } \\
\text { fication of existing government } \\
\text { storage facilities only. }\end{array}$ & $\begin{array}{l}\text { Decide to pursue large foreign } \\
\text { participation. }\end{array}$ \\
\hline \multicolumn{3}{|c|}{ Scenario III } \\
\hline NRC & $\begin{array}{l}\text { Restrict transshipments. Restrict } \\
\text { pool volume expansion. clarify } \\
\text { regulations for cask design. }\end{array}$ & $\begin{array}{l}\text { Delay cask design regulations. } \\
\text { Deny government AFR license. }\end{array}$ \\
\hline $\begin{array}{l}\text { State PUCs and } \\
\text { regulators }\end{array}$ & $\begin{array}{l}\text { Allow full pass-through of fee to } \\
\text { utility customers. Restrict pool } \\
\text { volume expansions. Restrict stor- } \\
\text { age of out-of-state spent fuel. }\end{array}$ & Disallow full pass-through. \\
\hline Utilities & $\begin{array}{l}\text { Express willingness to participate } \\
\text { in AFR program by prepayment of } \\
\text { fees. }\end{array}$ & $\begin{array}{l}\text { Actively pursue on-site expan- } \\
\text { and private AFRs and refuse to } \\
\text { participate in government AFRs. }\end{array}$ \\
\hline Intervenors & $\begin{array}{l}\text { Block pool expansions and/or trans- } \\
\text { shipments. }\end{array}$ & $\begin{array}{l}\text { Block transportation of spent } \\
\text { fuel to AFRs. }\end{array}$ \\
\hline Congress & $\begin{array}{l}\text { Approve legislative authority and } \\
\text { funding for a government AFR. }\end{array}$ & $\begin{array}{l}\text { Deny legislative authority for } \\
\text { or withhold full AFR funding. }\end{array}$ \\
\hline
\end{tabular}


Chapter 7

FINDINGS AND RECOMMENDATIONS

We find that variation in estimates of demand for government AFR storage facilities can be explained, in large part, by differences in assumptions about critical parameters, including:

- Regulatory treatment of the fee for government AFR services,

- The demand for nuclear energy,

- Political decisions regarding reprocessing and the breeder program,

- On-site storage expansion,

- Timing and availability of government AFRs,

- The extent to which transshipment of spent fuel is permitted,

- The availability of shipping casks,

- The extent of foreign demand for AFRs, and

- How and by whom AFRs are financed.

Depending on what assumptions are made about each of these critical parameters, predicted demand may vary dramatically, as Fig. 7.1 illustrates. The figure shows the number of government AFRs (of 5000-MTHM size) that would be demanded in 1985 and in 1993 under each of the three scenarios defined in Chap. 5. The estimates for 1993 range dramatically from a high of five AFRs under Scenario I to onIy one AFR in Scenario II.

To minimize the uncertainty about demand for government AFR storage and disposal facilities requires reducing the uncertainty about each of the critical parameters listed immediately above. Certain groups may be influential in reducing this uncertainty by their policies and actions. For example, in the short run (over the next five years) the most influential groups are likely to be the 


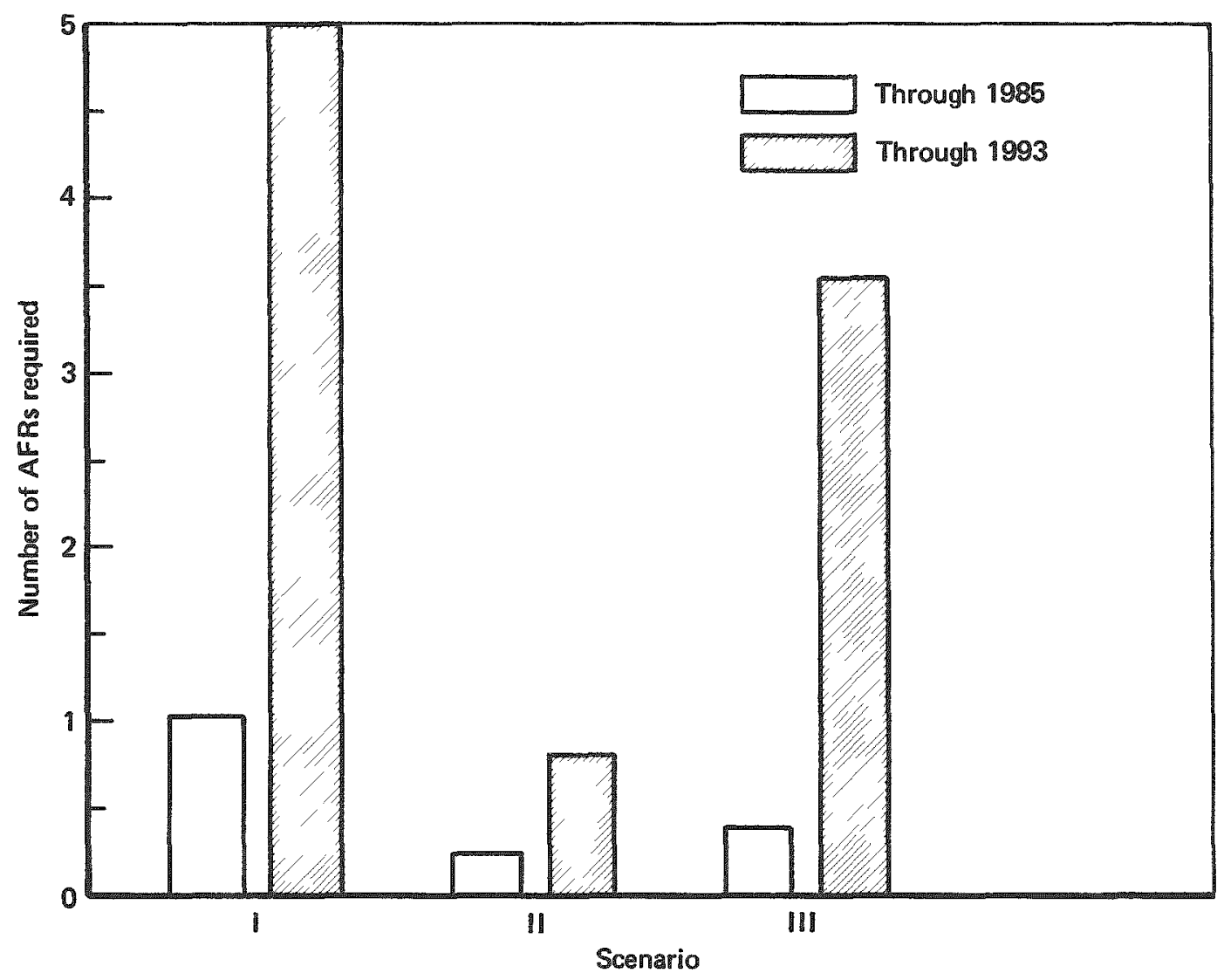

Fig. 7.1-AFR requirements for each scenario

utilities and the federal and state regulatory bodies--the NRC, EPA, and state PUCs--because their actions and policies can determine how much on-site expansion takes place. In the longer term (more than five years), Congress and DOE are likely to be most influential, because their actions will determine the size and availability of government AFRs--Congress through enabling legislation for funding, and $D O E$ through disbursement of the funds.

In view of the great amount of uncertainty about what actions different groups will take, in addition to uncertainties about future costs and future regulatory, political and foreign policies, it is not possible accurately to predict demand for government AFRs. However, certain groups may reduce uncertainties by taking actions such as the following: 
- The DoE, by setting requirements for accepting spent fuel (e.g., cooling period, level of on-site expansion, efforts to transship fuel), by setting the fee structure, by sponsoring research and development on shipping casks, and by setting criteria in conjunction with the State Department for accepting foreign spent fuel.

- The Nuclear Regulatory Commission (NRC), by regulating expansions of on-site storage and transshipment of spent fuel and by regulating shipping cask design criteria.

- The Environmental Protection Agency (EPA) and the Department of Transportation (DOT), by setting environmental and transportation standards which will affect the capability for on-site storage expansion, transfer of spent fuel, and operation of AFRs.

- State public utility commissions (PUCs) and regulatory agencies, by deciding the amount and the speed by which utilities will be allowed to recover costs of AFR fees, and by restricting on-site storage expansion, transshipments, or storage of spent fuel generated in other states.

- Utilities, by their efforts to transship spent fuel, to expand their own on-site storage capacities, and to participate in private decentralized (regiona1) AFRs.

- Congress, by approving legislative authority and funding for an AFR. 